\title{
Pliocene marine Bivalvia of Vale do Freixo (Pombal, Portugal): updated taxonomic list and discussion
}

\author{
Ricardo Jorge Pimentel ${ }^{1,3} \quad$ Pedro Miguel Callapez $^{2,3} \quad$ Paulo Legoinha $^{3}$
}

'Escola Secundária Dr. Joaquim de Carvalho, Figueira da Foz, Portugal

Rua Dra. Cristina Torres, 3080-210 Figueira da Foz, Portugal.

Pimentel E-mail: ricardopimentel@esjcff.pt

\begin{abstract}
${ }^{2}$ Universidade de Coimbra, CITEUC - Centro de Investigação da Terra e do Espaço da Universidade de Coimbra, Faculdade de Ciências e Tecnologia, Departamento de Ciências da Terra, Polo II

Rua Sílvio Lima, 3030-790 Coimbra, Portugal. Callapez E-mail: callapez@dct.uc.pt
\end{abstract}

${ }^{3}$ GEOBIOTEC, Department of Earth Sciences, NOVA School of Science and Technology Campus de Caparica P-2829 516 Caparica, Portugal. Legoinha E-mail: pal@fct.unl.pt

The exceptional Pliocene marine faunal assemblages of west central Portugal have been known since the late $19^{\text {th }}$ century. They include highly diverse molluscan faunas whose study is far to be completed. Discovered nearly 40 years ago, Vale do Freixo (Carnide, Pombal) is perhaps the most outstanding fossil site. Neverthless, the bivalves remain relatively unknown. This study focuses on the taxonomy of this relevant group of marine Mollusca. The research, based on a detailed sampling of three fossiliferous beds from the Carnide Formation, yielded a list of 85 species belonging to 75 genera and 32 families. Forty-three species are new for the Carnide area and twenty-three are reported for the first time in the Portuguese Pliocene, increasing to 115 the number of known species in the Mondego Basin in the Beira Litoral.

KEYWORDS Pliocene. Bivalvia. Taxonomy. Vale do Freixo. Portugal.

\section{INTRODUCTION}

The occurrence of fossil sites with well-preserved and highly diverse Pliocene marine faunal assemblages has long been reported from the mountain ranges of the Portuguese West Margin of Iberia (e.g. Carvalho and Colom, 1954; Carvalho, 1961, 1971;
Choffat, 1889; Cox, 1936, 1941; Dollfus and Cotter, 1909; Rocha and Ferreira, 1953; Teixeira and Zbyszewski, 1951; Zbyszewski, 1959). These sites occur in the northern Estremadura, and southern Beira Litoral provinces, between the towns of Caldas da Rainha and Pombal, where a thick Neogene marine, deltaic and alluvial deposits crop out (Cunha, 1992, 2019; Cunha et 
al., 1993, 2008, 2009; Ramos, 2008). These sucessions form a Pliocene shallow marine unit (Carnide Formation), transgressive on a substrate of Miocene claystones or Lower Jurassic carbonates and evaporites, and often starting with a basal conglomerate with well-rounded clasts and abraded bioclasts of Glycymeris and other rather large bivalves. Locally, the Carnide Formation is very fossiliferous, yielding highly diverse fossil fauna, which includes molluses and other invertebrates, as well abundant foraminifera, ostracods and other microfossils useful for biostratigraphical studies (e.g. Cachão, 1989, 1990; Cardoso, 1984; Diniz et al., 2016; Pais et al., 2010, 2013; Silva, 2001).

Besides its implication for the regional stratigraphy and depositional history of the Cenozoic Mondego Basin (Pais et al., 2012) and the diapiric valleys of Estremadura, this palaeontological record stands out because their paleobiogeographical position in the Pliocene Atlantic realm of southwestern Europe, midway from the Mediterranean and the northwest African margins to the colder waters of Biscay Bay, Channel and British Islands.

After the monograph of Dollfus and Cotter (1909), where the taxonomical composition and diversity of the bivalve faunas from the Caldas da Rainha outcrops and other related "classical sites" were first discussed, other works followed. The works of Brébion (1971, 1974), Cox (1936, 1941) and Zbyszewski (1959) focused on the rich assemblages of gastropods from these areas.

Cartographical work in the region of Carnide (Pombal) gave Teixeira and Zbyszewski (1951) the opportunity to study several new fossil sites, enlarging considerably the number of Portuguese Pliocene mollusc species. Several decades later, when quarry works discovered the Vale do Freixo outcrop near the southern end of Carnide village, Silva (1993, 2001) described a rich gastropod fauna collected from the well-exposed Pliocene beds. Further works (e.g. Silva et al., 2006, 2010, 2011) enhanced the importance of this fossil site for the Pliocene studies in Portugal, as well as for correlations with other coeval European sites, promoting a better knowledge of the Atlantic mollusc faunas of this interval and their interchanges with the closest biotic realms.

However, the bivalve fauna from Vale do Freixo was not studied in detail. Following on from the unpublished $\mathrm{MsC}$ dissertation of Pimentel (2018), the aim of this work is to update and discuss the taxonomic list of these bivalves based on the study of many newly collected specimens from the Vale do Freixo fossil site.

\section{GEOGRAFICAL AND GEOLOGICAL SETTING}

The fossil site of Vale do Freixo is located near Carnide, a rural village in the municipality of Pombal, in the Beira Litoral, west Portugal (Fig. 1). The sampled outcrops are located in a disabled quarry, with the coordinates: $39^{\circ} 53^{\prime} 00.35^{\prime} \mathrm{N} ; 8^{\circ} 43^{\prime} 49.45^{\prime} \mathrm{W}$. The site is in a private farm, accessible with the permission of the owner.

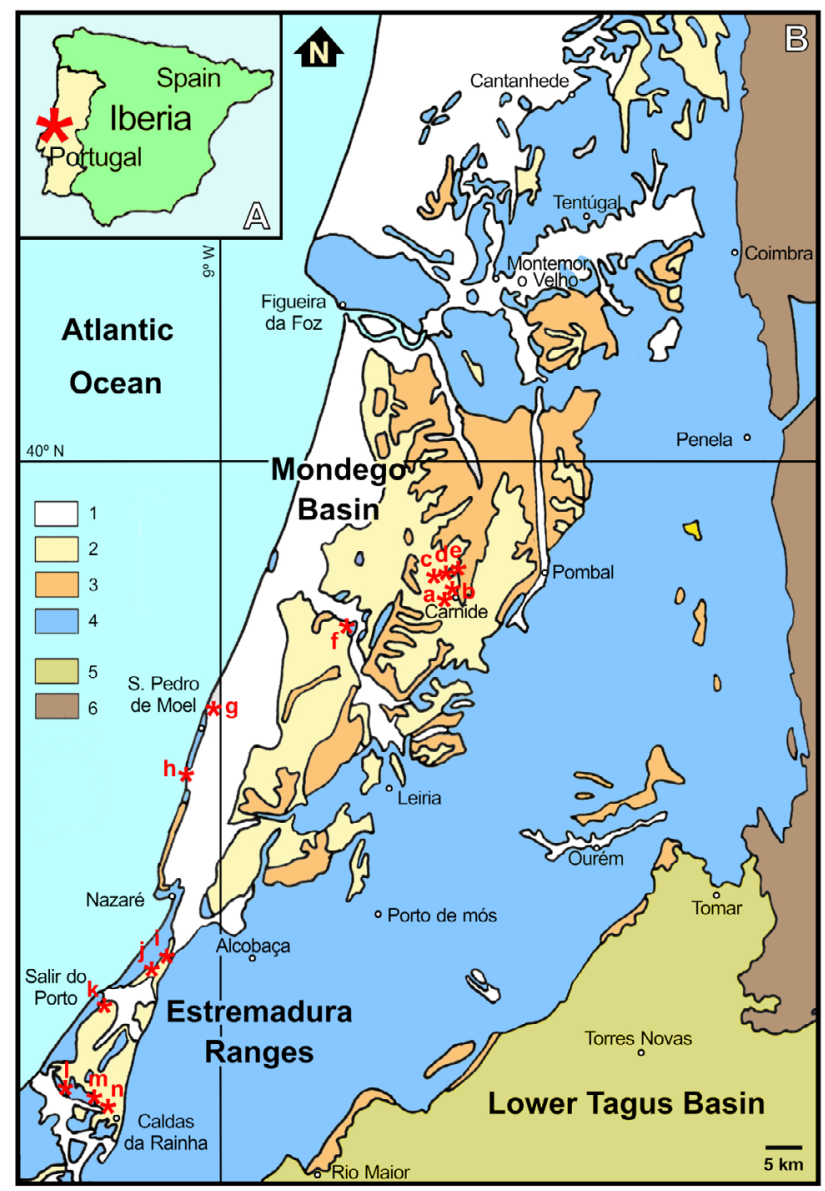

FIGURE 1. A) Location of the studied area in the Iberian Peninsula. B) Simplified geological sketch of the Cenozoic of the Mondego Basin and related tectono-sedimentary units of the West Portuguese Margin, with emphasis on the Pliocene and Quaternary deposits, and the location of Vale do Freixo and related marine fossil sites. 1= Quaternary; 2= Pliocene (including the Carnide Fm.); 3= Palaeogene and Miocene; $4=$ Meosozoic series of the Lusitanian Basin; 5= Neogene and Quaternary infill of the Lower Tagus Basin; 6= Variscan basement of the Iberian Massif. Main fossil sites: $a=$ Vale do Freixo; $\mathrm{b}=$ Igreja de Carnide; $\mathrm{c}=$ Vale da Bouchada; $\mathrm{d}=$ Vale Farpado; $\mathrm{e}=$ Vale da Cabra; $\mathrm{f}=$ Monte Real; $\mathrm{g}=$ Mina; $\mathrm{h}=$ Senhora da Vitória; $\mathrm{i}=$ Famalicão; j= Bom Jesus; $k=$ Salir do Porto; l= Nadadouro; $m=$ Casal do Negreiro; $n=$ Águas Santas.

The Pliocene beds are almost horizontal and extend over both sides of the nearby Carnide Valley, where they follow an alignment of slightly sloped hills cut in siliciclastic beds. Vale do Freixo and other correlative fossiliferous occurrences correspond to scattered lenticular beds exposed along the western side of the valley.

The fossiliferous beds overlie unconformably middle Miocene greyish claystones (Amor Formation, Pais et al., 2010, 2012). They locally record the basal parasequence of the succession described as Barracão Group, with marine to alluvial and lacustrine facies (Pais et al., 2010, 2012, 2013). The 1:50,000 Geological Map of Portugal (23-A, Pombal set) reports this unit as "P - Marine Pliocene of 
Carnide Valley" (Manuppella et al., 1978). The fossiliferous level has a lenticular geometry and belongs to the Carnide Formation of the Barracão Group (Cachão, 1989, 1990). Facies are of siliciclastic nature and their association suggests deposition through an inner shelf shoreface. Facies also record the proximal, landward deposition of transgressive and highstand system-tracts over a lowstand erosive surface.

The transgressive parasequence (Fig. 2) consists of a continuous condensed bed of dark greyish, poorly graded, oligomitic conglomerate (bed " 2 ") rich in wellrounded quartz and quartzite clasts, and concentrations of disarticulated valves of Glycymeris, among other medium to large-sized bivalves, with their commissures facing down. This basal conglomerate is $0.5 \mathrm{~m}$ thick on average, and has an erosive transgressive base. The following highstand bed is a greyish, poorly graded, medium- to finegrained, massive sandstone (bed " 3 "; $0.4 \mathrm{~m}$ ), quite rich in well-preserved fossils, including many articulated infaunal bivalves. It is overlain by a fairly graded, yellowish to lightbrown fine-grained sandstone (bed " 4 "; $0.3 \mathrm{~m}$ ), also rather fossiliferous, with many infaunal tellinid bivalves in life position, showing residues of original color and of hinge ligament. The topmost bed is a thin, light-brownish, highly plastic clay with erosive base and variable lateral thickness (bed " 5 "; 0.05 to $0.15 \mathrm{~m}$ ), suggesting a local lack of accommodation space related to the return to a regressive trend. It is likely that this impermeable non-fossiliferous layer has contributed to the exceptional preservation of the fossil assemblages in the underlying beds, through the inhibition of water percolation (Pimentel, 2018; Pimentel et al., 2019).

The top of the fossiliferous section of Vale do Freixo (Carnide Formation) is an erosive surface. The section is overlain by the siliciclastics of the Ilha Formation (sensu Carvalho, 1998), which consist of medium to coarsegrained micaceous sandstones with small, well-rounded, gravel clasts of whitish quartzite scattered in the matrix. This rather monotonous sequence of apparently nonfossiliferous beds suggests deposition near an intertidal environment with high energetic oscillation (Carvalho et al., 2005c).

Cachão (1990) determined the Pliocene age of the Vale do Freixo fossil assemblages based on calcareous nanofossils, CN12a biozone of Okada and Bukry (1980) and the NN16 unit of Martini (1971). Moreover, Silva (2001) and Silva et al. (2010) suggested that the rich gastropod fauna could be coeval with the Mediterranean Pliocene Molluscan Unit 1 (MPMU1) (Monegatti and Raffi, 2001; Raffi and Monegatti, 1993), and thus essentially somewhat older than 3.0Ma. It has been estimated that the chronostratigraphical range of the fossiliferous interval extens from the top of the Zanclean to the lower half of the Piacenzian (3.70-3.61Ma to 3.0Ma). On the other hand, on the basis of the ${ }^{87} \mathrm{Sr} /{ }^{86} \mathrm{Sr}$ isotopic data obtained from the valves of Palliolum excisum, Silva (2001) placed the lower boundary at $3.52 \mathrm{Ma}$.

\section{MATERIALS AND METHODS}

Sampling was made bed by bed, following the stratigraphic section. Most specimens were collected individually, which was complemented by a volumetric bulk sample for each bed. Fieldwork also included taphonomic observations. Because large specimens occurred in unconsolidated sediments, they were easily extracted in the outcrop.

In the laboratory, the mechanical preparation and cleaning were often difficult due to the extreme fragility of many fossil shells, such as those of Tellinidae, Lucinidae and Mactridae. For these shells, the use of water to remove the sediment matrix was avoided, and a less aggressive meticulous dry cleaning was adopted.

Bulk-samples collected for volumetric purposes were washed through a column of sieves with meshes from $2 \mathrm{~mm}$ to $0.125 \mathrm{~mm}$. Macro and microfossils from these fractions were picked up using a binocular and classified into taxonomic groups. The bivalve specimens were classified into genus and species.

A bulk collection of c.1,400 specimens was obtained. Several specimens were partially covered by matrix, and others consolidated with application of a film of transparent glue dissolved in acetone.

For the commonest species, we selected the bestpreserved specimens. For the remaining species, the criterion was to use all specimens, even if incomplete or badly preserved. All specimens were numbered and catalogued with the references RP-VF2-B001 to RP-VF2-B061, RPVF3-B001 to RP-VF3-B738, and RP-VF4-B001 to RPVF4-B385. The collection is housed in the Earth Sciences Department of the University of Coimbra.

\section{UPDATED LIST OF BIVALVES AND TAXONOMIC NOTES}

The present taxonomical study allowed the identification of 82 species of Bivalvia plus three species left in open nomenclature (Modiolus sp., Gregariella sp., Ensis cf. siliqua). Systematics follows Bieler et al. (2010, 2014), Carter et al. (2011) and Huber (2015) for Tellinidae, and Pérez (2019) for Carditidae. 

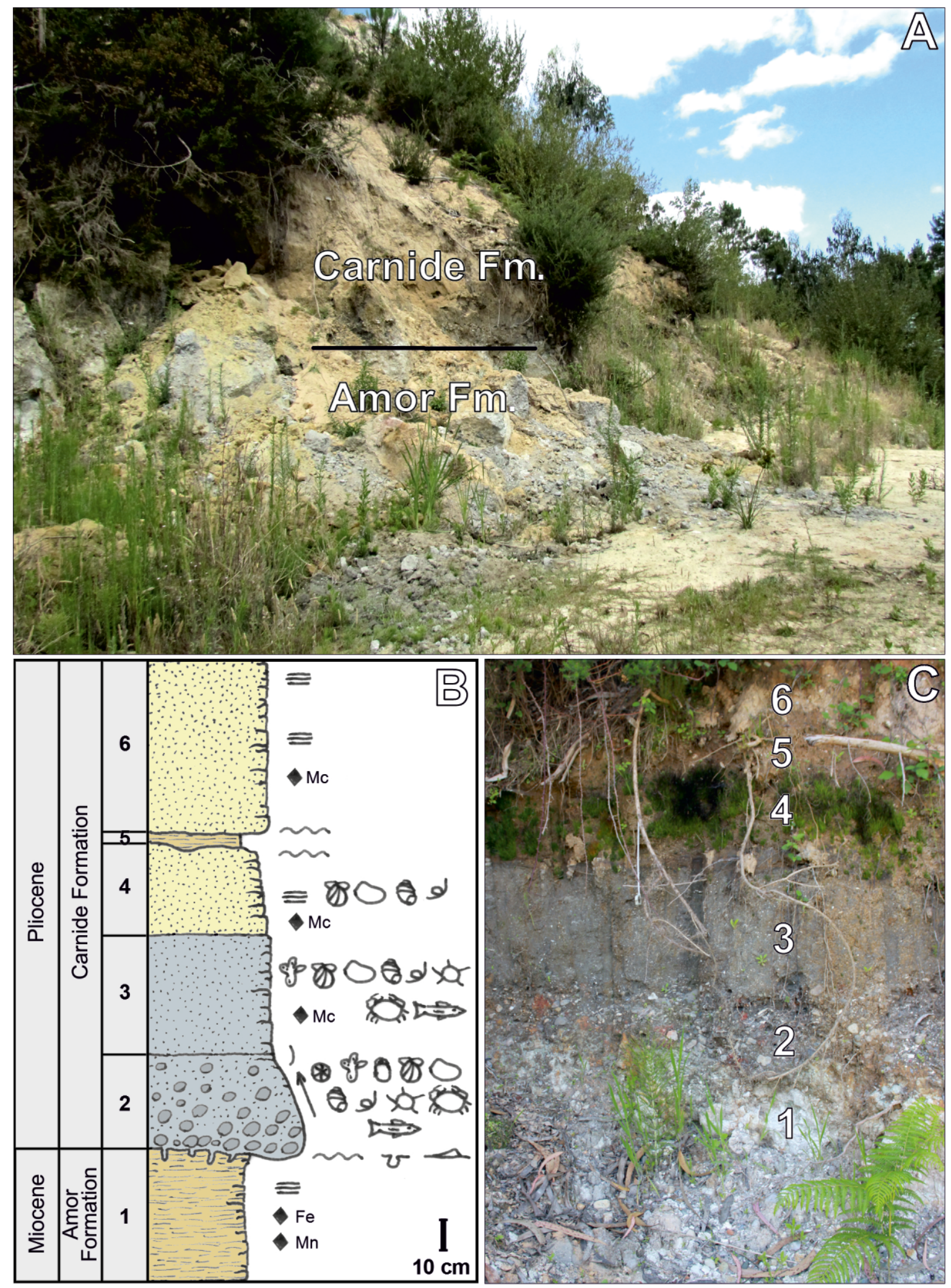

FIGURE 2. A) General field view of the Pliocene fossil site of Vale do Freixo (Carnide, Pombal, west Portugal). B) Stratigraphic section of the outcrop with the beds enhanced by different colours: $a=$ Scleractinian corals; $b=$ Bryozoans; $c=$ Terebratulid brachiopods; $d=$ Bivalves (Protobranchia and Pteriomorphia); $\mathrm{e}=$ Bivalves (Heteroconchia); $\mathrm{f}=$ Gastropods; $\mathrm{g}=$ Serpulid worms; $\mathrm{h}=$ Echinoids; $\mathrm{i}=$ Crustaceans; $\mathrm{j}=$ Fish remains; $\mathrm{k}=$ Unconformities; $\mathrm{I}=$ Laminated structure; $\mathrm{m}=$ Gradual transition; $\mathrm{n}=$ Borings; $\mathrm{O}=$ Hard-ground surface; $\mathrm{p}=$ Grain-size finning upwards; $q=$ Micaceous grains; $r=\mid$ ron nodules and impregnations; $s=$ Manganese impregnations. C) Detail of Vale do Freixo fossil site (1= Amor Fm.; 2 to 6= Carnide Fm.). 
For the specific detemination, we used the works of Brocchi (1814), Bucquoy et al. (1887-1898), Chirli (2014, 2015, 2016), Dollfus and Cotter (1909), Huber (2010, 2015), Lauriat-Rage (1981, 1982, 1986), Lozano-Francisco (1997), Nobre (1938-1940), Poppe and Goto (1993) and Sacco (1897a, 1897b, 1898a, 1898b, 1899, 1900, 1901).

The updated bivalve list proposed here for the Vale do Freixo fossil site includes several new occurrences in the Pliocene of Portugal (*) (Figs. 3; 4) and many species known in other Portuguese sites, but not yet reported in the region of Carnide (**). The bivalve species are:

Class: Bivalvia LINNAEUS, 1758

Subclass: Protobranchia PELSENEER, 1889

Order: Nuculida DALL, 1889

Superfamily: Nuculoidea GRAY, 1824

Family: Nuculidae GRAY, 1824

GENUS Ennucula IREDALE, 1931

Ennucula laevigata (J. SOWERBY, 1818) (*)

GENUS Nucula DE LAMARCK, 1799

Nucula nucleus (LINNAEUS, 1758)

Order: Nuculanida J.G. CARTER, D.C. CAMPBELL AND M.R. CAMPBELL, 2000

Superfamily: Nuculanoidea H. ADAMS AND A. ADAMS,

$$
1858 \text { (1854) }
$$

Family: Nuculanidae H. ADAMS AND A. ADAMS,

$$
1858 \text { (1854) }
$$

GENUS Lembulus RISSO, 1826

Lembulus pella (LINNAEUS, 1758)

Subclass: Autobranchia GROBBEN, 1894

Infraclass: Pteriomorphia BEURLEN, 1944

Order: Mytilida FÉRUSSAC, 1822

Superfamily: Mytiloidea RAFINESQUE, 1815
Family: Mytilidae RAFINESQUE, 1815

Subfamily: Modiolinae G. TERMIER AND H. TERMIER, 1950

GENUS Modiolus DE LAMARCK, 1799

Modiolus sp. (**)

Family: Crenellidae GRAY, 1840

Subfamily: Musculinae IREDALE, 1939

GENUS Gregariella MONTEROSATO, 1883

Gregariella sp. (*)

Order: Arcida STOLICZKA, 1871

Superfamily: Arcoidea DE LAMARCK, 1809

Family: Arcidae DE LAMARCK, 1809

GENUS Arca LINNAEUS, 1758

Arca tetragona POLI, 1795 (**)

GENUS Barbatia GRAY, 1842

Barbatia mytiloides (BROCCHI, 1814)

Subfamily: Anadarinae REINHART, 1935

GENUS Anadara GRAY, 1847

Anadara diluvii (DE LAMARCK, 1805) (**)

Anadara pectinata (BROCCHI, 1814) (**)

Family: Noetiidae STEWART, 1930

GENUS Striarca CONRAD, 1862

Striarca lactea (LINNAEUS, 1758)

Family: Glycymerididae DALL, 1908 (1847)

Subfamily: Glycymeridinae DALL, 1908 (1847)

GENUS Glycymeris DA COSTA, 1778

Glycymeris glycymeris (LINNAEUS, 1758)

Order: Ostreida FÉRUSSAC, 1822

Superfamily: Ostreoidea RAFINESQUE, 1815 


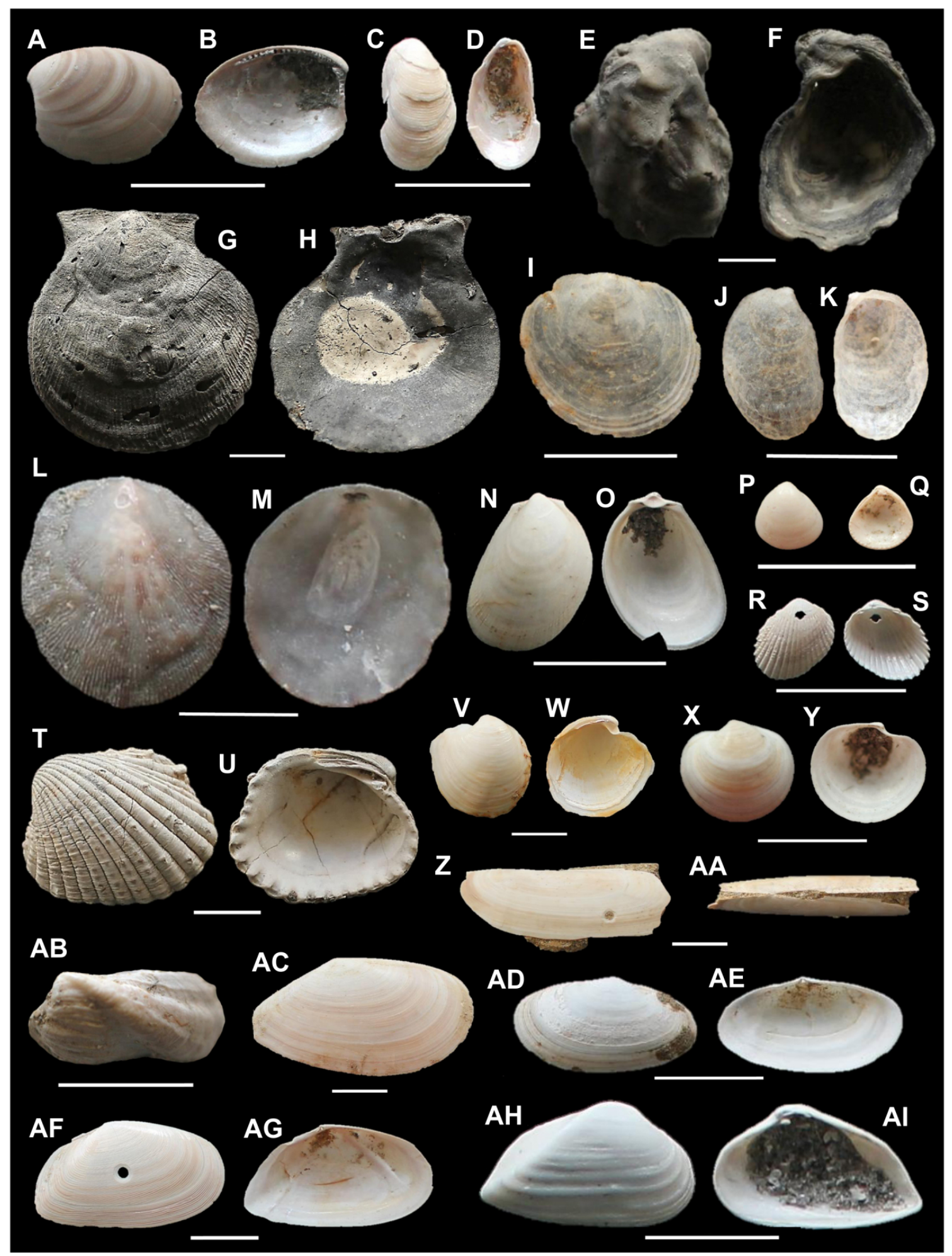

FIGURE 3. A-B) Ennucula laevigata (right valve RP-VF3-B650); C-D) Gregariella sp. (left valve RP-VF4-B382); E-F) Neopycnodonte cochlear (left valve RP-VF3-B348); G-H) Hinnites ercolanianus (left valve RP-VF2-B012); I-K) Heteranomia squamula (left valves RP-VF3-B737 and RPVF3-B738); L-M) Pododesmus squama (left valve RP-VF3-B597); N-O) Limaria loscombi (left valve RP-VF3-B364); P-Q) Goodallia triangularis (right valve RP-VF4-B347); R-S) Parvicardium scriptum (right valve RP-VF3-B735); T-U) Centrocardita aculeata (left valve RP-VF3-B012); V-W) Megaxinus transversus (left valve RP-VF4-B067); X-Y) Loripinus fragilis (left valve RP-VF3-B736); Z-AA) Phaxas pellucidus (articulated specimen RP-VF4-B275); AB) Hiatella rugosa (left valve RP-VF3-B017); AC) Bosemprella incarnata (right valve RP-VF4-B338); AD-AE) Gari tellinella (left valve RP-VF4-B190); AF-AG) Oudardia compressa (right valve RP-VF4-B326 and left valve RP-VF4-B329); AH-Al) Corbula revoluta (right valve RP-VF3-B377). Scale bars $=1 \mathrm{~cm}$. 


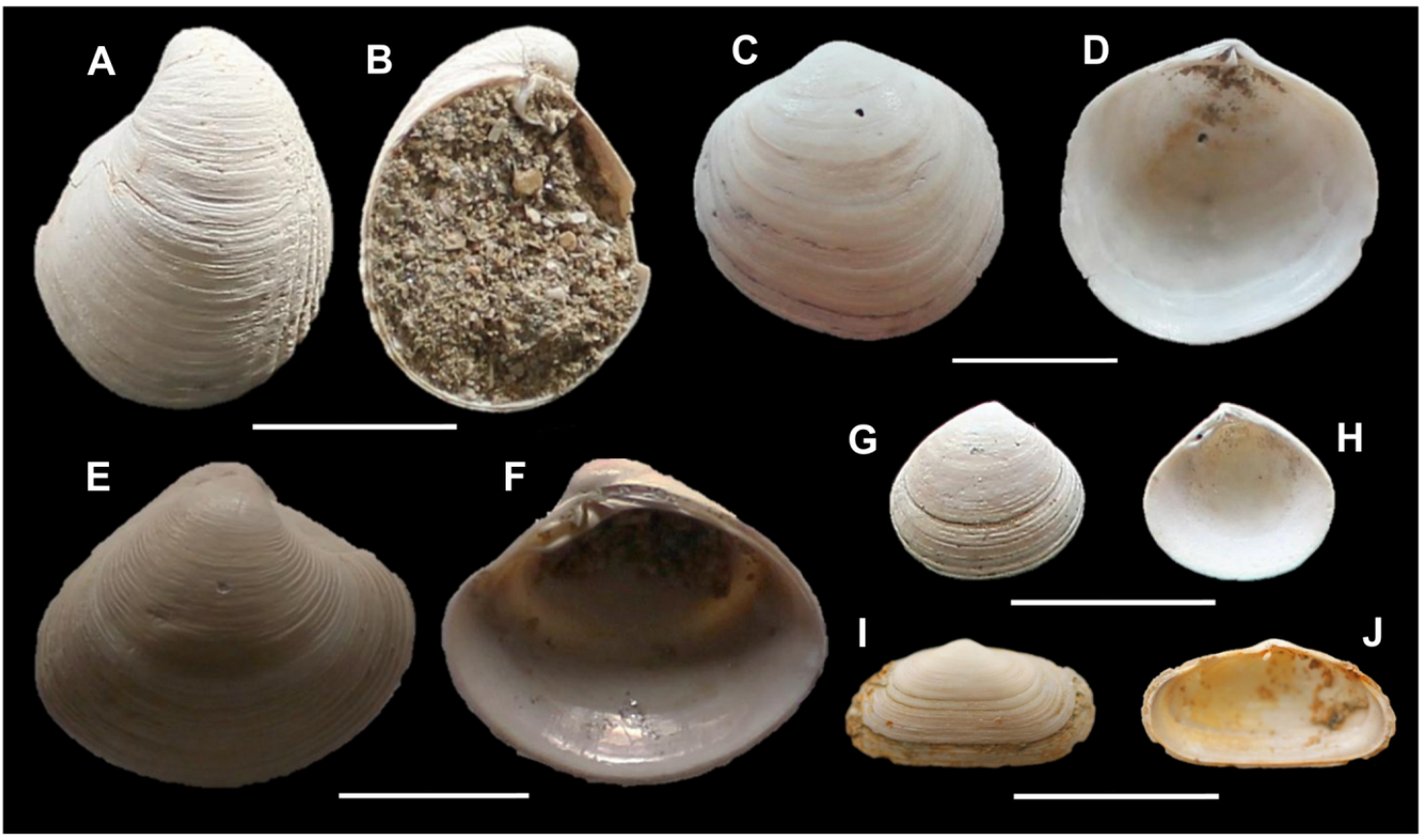

FIGURE 4. A-B) Cardilia michelottii (left valve RP-VF4-B005); C-D) Diplodonta rotundata (left valve RP-VF3-B665); E-F) Pitar rudis (right valve RPVF4-B252); G-H) Gouldia minima (right valve RP-VF3-B689); I-J) Spaniorinus reconditus (right valve RP-VF4-B315). Scale bars= 1cm.

Family: Ostreidae RAFINESQUE, 1815

Subfamily: Ostreinae RAFINESQUE, 1815

\section{GENUS Ostrea LINNAEUS, 1758}

Ostrea edulis LINNAEUS, 1758

Family: Gryphaeidae VIALOV, 1936

Subfamily: Pycnodonteinae STENZEL, 1959

GENUS Neopycnodonte STENZEL, 1971

Neopycnodonte cochlear (POLI, 1795) (*)

Superfamily: Pinnoidea LEACH, 1819

Family: Pinnidae LEACH, 1819

GENUS Atrina GRAY, 1842

Atrina fragilis (PENNANT, 1777)

Superfamily: Pterioidea GRAY, 1847 (1820)

Family: Pteriidae GRAY, 1847 (1820)

GENUS Pteria SCOPOLI, 1777
Pteria hirundo (LINNAEUS, 1758)

Order: Pectinida GRAY, 1854a

Superfamily: Pectinoidea RAFINESQUE, 1815

Family: Pectinidae RAFINESQUE, 1815

Subfamily: Pectininae RAFINESQUE, 1815

GENUS Aequipecten P. FISCHER, 1886

Aequipecten opercularis (LINNAEUS, 1758) (**)

GENUS Flexopecten SACCO, 1897

Flexopecten flexuosus (POLI, 1795) (**)

GENUS Pecten O.F. MÜLLER, 1776

Pecten benedictus DE LAMARCK, 1819

Subfamily: Palliolinae KOROBKOV IN EBERZIN, 1960

GENUS Palliolum MONTEROSATO, 1884

Palliolum excisum (BRONN, 1831)

Subfamily: Pedinae BRONN, 1862 
GENUS Hinnites DEFRANCE, 1821

Hinnites crispus (BROCCHI, 1814) (**)

Hinnites ercolanianus COCCONI, 1873 (*)

GENUS Mimachlamys IREDALE, 1929

Mimachlamys varia (LINNAEUS, 1758) (**)

GENUS Talochlamys IREDALE, 1929

Talochlamys multistriata (POLI, 1795)

Family: Propeamussiidae Аввотт, 1954

GENUS Similipecten WINCKWORTH, 1932

Similipecten similis (LASKEY, 1811)

Superfamily: Anomioidea RAFINESQUE, 1815

Family: Anomiidae RAFINESQUE, 1815

GENUS Heteranomia WINCKWORTH, 1922

Heteranomia squamula (LINNAEUS, 1758) (*)

GENUS Pododesmus PHILIPPI, 1837

Pododesmus squama (GMELIN, 1791) (*)

Order: Limida MOORE, 1952

Superfamily: Limoidea RAFINESQUE, 1815

Family: Limidae RAFINESQUE, 1815

GENUS Lima BRUGUIÈRE, 1797

Lima lima (LINNAEUS, 1758) (**)

GENUS Limaria LINK, 1807

Limaria loscombi (G.B. SOWERBY I, 1823) (*)

Limaria tuberculata (OLIVI, 1792)

Infraclass: Heteroconchia HERTWIG, 1895

Superorder: Imparidentia BIELER, MIKKELSEN AND GIRIBET, 2014

Order: Carditida DALL, 1889
Superfamily: Crassatelloidea FÉRUSSAC, 1822

Family: Astartidae D’ORBIGNY, 1844 (1840)

GENUS Astarte J. SOWERBY, 1816

Astarte fusca (POLI, 1791)

GENUS Digitaria S.v. WOOD, 1853

Digitaria digitaria (LINNAEUS, 1758)

GENUS Goodallia TURTON, 1822

Goodallia triangularis (MONTAGU, 1803) (*)

Superfamily: Carditoidea FÉRUSSAC, 1822

Family: Carditidae FÉRUSSAC, 1822

Subfamily: Carditinae FÉRUSSAC, 1822

GENUS Cardita BRUGUIÈRE, 1792

Cardita calyculata (LINNAEUS, 1758) (**)

Subfamily: Venericardiinae CHAVAN, 1969

GENUS Cardites LINK, 1807

Cardites antiquatus (LINNAEUS, 1758) (**)

GENUS Megacardita SACCO, 1899

Megacardita striatissima (CAILLIAUD, in MAYER, 1868)

Subfamily: Carditamerinae CHAVAN, 1969

GENUS Centrocardita SACCO, 1899

Centrocardita aculeata (POLI, 1795) (*)

Subfamily: Scalaricarditinae PÉREZ, 2019

GENUS Scalaricardita SACCO, 1899

Scalaricardita scalaris (J. DE C. SOWERBY, 1825)

Order: Lucinida GRAY, 1854a

Superfamily: Lucinoidea J. FLEMING, 1828

Family: Lucinidae J. FLEMING, 1828 
Subfamily: Codakiinae KOROBKOV, 1954

GENUS Lucinoma DALL, 1901

Lucinoma borealis (LINNAEUS, 1767)

Subfamily: Lucininae J. FLEMING, 1828

GENUS Megaxinus BRUGNONE, 1880

Megaxinus transversus (BRONN, 1831) (*)

Subfamily: Pegophyseminae J.D. TAYLOR AND GLOVER, 2011

GENUS Loripinus MONTEROSATO, 1884

Loripinus fragilis (PHILIPPI, 1836) (*)

Order: Adapedonta COSSMANN AND PEYROT, 1909

Superfamily: Solenoidea DE LAMARCK, 1809

Family: Pharidae H. ADAMS AND A. ADAMS, 1856

Subfamily: Pharinae H. ADAMS AND A. ADAMS, 1856

GENUS Pharus GRAY, 1840

Pharus legumen (LINNAEUS, 1758)

GENUS Phaxas LEACH IN GRAY, 1852

Phaxas pellucidus (PENNANT, 1777) (*)

Subfamily: Cultellinae DAVIES, 1935

GENUS Ensis SCHUMACHER, 1817

Ensis cf. siliqua (LINNAEUS, 1758)

Superfamily: Hiatelloidea GRAY, 1824

Family: Hiatellidae GRAY, 1824

GENUS Hiatella BOSC, 1801

Hiatella rugosa (LINNAEUS, 1767) (*)

Order: Cardiida FÉRUSSAC, 1822

Superfamily: Cardioidea DE LAMARCK, 1809

Family: Cardiidae DE LAMARCK, 1809

Subfamily: Cardiinae DE LAMARCK, 1809
GENUS Procardium TER POORTEN AND LA PERNA, 2017

Procardium diluvianum (DE LAMARCK, 1819)

Subfamily: Lymnocardiinae STOLICZKA, 1870

GENUS Acanthocardia GRAY, 1851

Acanthocardia aculeata (LINNAEUS, 1758) (**)

GENUS Papillicardium SACCO, 1899

Papillicardium papillosum (POLI, 1791) (**)

GENUS Parvicardium MONTEROSATO, 1884

Parvicardium scriptum (BUCQUOY, DAUTZENBERG

AND DOLLFUS, 1892) (*)

Subfamily: Laevicardiinae KEEN, 1951

GENUS Laevicardium SWAINSON, 1840

Laevicardium crassum (GMELIN, 1791)

Subfamily: Orthocardiinae SCHNEIDER, 2002

GENUS Europicardium multicostatum (BROCCHI, 1814)

Superfamily: Tellinoidea de BLAINVILLE, 1814

Family: Tellinidae de BLAINVILLE, 1814

Subfamily: Arcopagiinae M. HUBER, LANGLEIT AND

KREIPL, 2015

GENUS Arcopagia T. BROWN, 1827

Arcopagia corbis (BRONN, 1831)

Arcopagia crassa (PENNANT, 1777)

Subfamily: Gastraninae M. HUBER, LANGLEIT AND KREIPL, 2015

GENUS Gastrana fragilis (LINNAEUS, 1758) (**)

Subfamily: Macominae OLSSON, 1961

GENUS Macomopsis SACCO, 1901

Macomopsis elliptica (BROCCHI, 1814) 
Subfamily: Tellininae DE BLAINVILLE, 1814

GENUS Bosemprella M. HUBER, LANGLEIT AND KREIPL, 2015

Bosemprella incarnata (LINNAEUS, 1758) (*)

GENUS Oudardia MONTEROSATO, 1884

Oudardia compressa (BROCCHI, 1814) (*)

GENUS Peronidia DALL, 1900a

Peronidia albicans (GMELIN, 1791) (**)

Family: Donacidae J. FLEMING, 1828

GENUS Donax LINNAEUS, 1758

Donax variegatus (GMELIN, 1791)

Family: Psammobiidae J. FLEMING, 1828

GENUS Gari SCHUMACHER, 1817

Gari depressa (PENNANT, 1777) (**)

Gari tellinella (DE LAMARCK, 1818) (*)

Garifervensis (GMELIN, 1791)

Family: Semelidae STOLICZKA, 1870 (1825)

GENUS $\boldsymbol{A} \boldsymbol{b} \boldsymbol{r} \boldsymbol{a}$ DE LAMARCK, 1818

Abra alba (W. WOOD, 1802) (**)

Abra prismatica (MONTAGU, 1808)

Order: Venerida GRAY, 1854a

Superfamily: Chamoidea DE LAMARCK, 1809

Family: Chamidae DE LAMARCK, 1809

GENUS Chama LINNAEUS, 1758

Chama gryphoides LINNAEUS, $1758(* *)$

Superfamily: Mactroidea DE LAMARCK, 1809

Family: Mactridae DE LAMARCK, 1809

Subfamily: Mactrinae DE LAMARCK, 1809

GENUS Mactra LINNAEUS, 1767
Mactra stultorum (LINNAEUS, 1758)

GENUS Spisula GRAY, 1837

Spisula subtruncata (DA COSTA, 1778)

Spisula solida (LINNAEUS, 1758)

Subfamily: Lutrariinae GRAY, 1853

GENUS Lutraria DE LAMARCK, 1799

Lutraria lutraria (LINNAEUS, 1758) (**)

Family: Cardiliidae P. FISCHER, 1887

GENUS Cardilia DESHAYES, 1835

Cardilia michelottii DESHAYES, 1844 (*)

Superfamily: Ungulinoidea GRAY, 1854b

Family: Ungulinidae GRAY, 1854b

GENUS Diplodonta BRONN, 1831

Diplodonta rotundata (MONTAGU, 1803) (*)

GENUS Callista POLI, 1791

Callista chione (LINNAEUS, 1758)

GENUS Chamelea MÖRCH, 1853

Chamelea gallina (LINNAEUS, 1758)

GENUS Circomphalus MÖRCH, 1853

Circomphalus foliaceolamellosus (DILLWYN, 1817)

GENUS Clausinella GRAY, 1851

Clausinella fasciata (DA COSTA, 1778)

GENUS Dosinia SCOPOLI, 1777

Dosinia lupinus (LINNAEUS, 1758)

GENUS Gouldia C.B. ADAMS, 1847

Gouldia minima (MONTAGU, 1803) (*)

GENUS Pitar RÖMER, 1857

Pitar rudis (POLI, 1795) (*) 
GENUS Tapes MEGERLE VON MÜHLFELD, 1811

Tapes vetula (DE BASTEROT, 1825)

GENUS Timoclea T. BROWN, 1827

Timoclea ovata (PENNANT, 1777)

GENUS Venus LINNAEUS, 1758

Venus casina LINNAEUS, 1758

Venus verrucosa LINNAEUS, 1758

Superfamily: Galeommatoidea GRAY, 1840

Family: Galeommatidae GRAY, 1840

GENUS Spaniorinus DALL, 1900b

Spaniorinus reconditus (P. FISCHER, 1872) (*)

Family: Lasaeidae GRAY, 1842

GENUS Scacchia PHILIPPI, 1844

Scacchia oblonga (PHILIPPI, 1836) (**)

Order Myida STOLICZKA, 1870

Superfamily: Myoidea DE LAMARCK, 1809

Family: Corbulidae DE LAMARCK, 1818

GENUS Corbula BRUGUIÈRE, 1797

Corbula gibba (OLIVI, 1792)

\section{Corbula revoluta (BROCCHI, 1814) (*)}

For the Nuculidae with non-crenulate ventral border, we adopted the genus Ennucula IREDALE, 1931, following la Perna (2007).

Following the criteria of several authors (e.g. LauriatRage, 1981), we have considered Ostrea lamellosa BROCCHI, 1814 and $O$. edulis LINNAEUS, 1758 as a single valid species. For the Pododesmus species, we followed Holmes (2017).

After Huber (2010), Venus incrassata BROCCHI, 1814 as well as all synonymy followed by several authors, and based on the original diagnosis of Brocchi (1814) have to be considered as belonging to the recent species Astarte fusca (POLI, 1791).
La Perna et al. (2017) proposed a new species designation for Cardita striatissima var. abbreviata DOLLFUS AND COTTER, 1909 as Megacardita redoniana n. sp., and considered that its subordination to Megacardita SACCO, 1899 was provisory (la Perna et al., 2018). By this reason, we opted by a conservative view of the Vale do Freixo specimens as $C$. striatissima, in line with LauriatRage et al. (1989), and Carvalho et al. (2005b) who made a quantitative study of infraespecific variation for the samplepopulations of beds " 2 " and " 3 ".

Cardita scalaris J.C. DE SOWERBY, 1825 is here placed in genus Scalaricardita SACCO, 1899 and for the Carditidae we followed the systematic scheme suggested by Pérez (2019).

Cardium hians BROCCHI, 1814 in Procardium TER POORTEN AND LA PERNA, 2017. The mention of this species in the Pliocene beds of Alfeite and S. Joanes (Zbyszewski, 1943), and in the Carnide area (Teixeira and Zbyszewsky, 1951; Zbyszewski, 1959) seem to correspond to occurrences of $P$. diluvianum for the Portuguese Neogene.

After la Perna (2017), Cardium multicostatum BROCCHI, 1814, which has been widely cited as Trachycardium multicostatum (BROCCHI, 1814), should be allocated to Europicardium POPOV, 1977.

In line with the propositions of Fisher-Piette and Métivier (1971) and Canapa et al. (2003), that the genus Paphia RÖDING, 1798 should be restraint to the Indo-Pacific Realm, we considered Tapes MEGERLE VON MÜHLFELD, 1811 as the most adequate genus for Venus vetula DE BASTEROT, 1825.

\section{DISCUSSION}

The whole assemblage of bivalve molluscs here identified from beds " 2 " to " 4 " of Vale do Freixo amounts 85 species (Tables $1 ; 2$ ) distributed in 32 families and 75 genera. The families with more species are Veneridae (11 species), Pectinidae and Tellinidae (eight species each). Its taxonomical composition and high-diversity are in line with previous observations based on the gastropod fauna (Gili et al., 1995; Landau et al., 2006, 2007; Landau and Silva, 2006a, b; Silva, 1991, 1993, 1995, 2001, 2002, 2003; Silva et al., 2000, 2006, 2010, 2011; Silva and Landau, 2007, 2009), who suggest an inner shelf depositional environment with sandy substrates and normal salinity conditions, ranging in the infralittoral zone within depths of $24 \mathrm{~m}$ and above.

The richness and abundance of the bivalves are similar to those of the gastropods. The molluscan faunas also contain scaphopods and polyplacophora (Dell' Angelo and Silva, 2003). 
TABLE 1. Bivalvia species from Vale do Freixo and their occurrence in other Beira Litoral and Estremadura localities. Subclasses Protobranchia and Autobranchia, Infraclass Pteriomorphia. $\mathrm{CN}=$ Carnide ( $\mathrm{b}=$ Igreja de Carnide, $\mathrm{C}=$ Vale da Bouchada, $\mathrm{d}=\mathrm{Vale}$ Farpado, e= Vale da Cabra); MR= Monte-Real; PM= S. Pedro de Moel (g= Mina, h= Senhora da Vitória); NZ= Nazaré (i= Famalicão, j= Bom Jesus, k= Salir do Porto) and CR= Caldas da Rainha (I= Nadadouro, $m=$ Casal do Negreiro, $n=$ Águas Santas); see Figure 1 for the localities. Data from: Carvalho et al., 2005a; Choffat, 1889; Cox, 1941; Dollfus and Cotter, 1909; Manuppella et al., 1978; Pimentel, 2018; Pimentel et al., 2018; Teixeira and Zbyszewski, 1951; Zbyszewski, 1959; Zbyszewski and Moitinho de Almeida, 1960; Zbyszewski et al., 1961

\begin{tabular}{|c|c|c|c|c|c|}
\hline Vale do Freixo (Carnide) & $\begin{array}{c}\mathrm{CN} \\
(\mathrm{b}-\mathrm{e})\end{array}$ & $\begin{array}{c}\text { MR } \\
\text { (f) }\end{array}$ & $\begin{array}{c}\text { PM } \\
(g-h)\end{array}$ & $\begin{array}{l}\mathrm{NZ} \\
(\mathrm{i}-\mathrm{k})\end{array}$ & $\begin{array}{l}\text { CR } \\
(I-n)\end{array}$ \\
\hline \multicolumn{6}{|l|}{ Ennucula laevigata (J. SoWERBY, 1818) } \\
\hline Nucula nucleus (LINNAEUs, 1758) & & $X$ & & & $X$ \\
\hline Lembulus pella (LINNAEUS, 1758) & $X$ & & & & $\mathrm{X}$ \\
\hline Modiolus sp. & & & & & $X$ \\
\hline \multicolumn{6}{|l|}{ Gregariella sp. } \\
\hline Arca tetragona PoLI, 1795 & & & $X$ & & $X$ \\
\hline Barbatia mytiloides (BRoccHI, 1814) & $\mathrm{X}$ & & & $X$ & $X$ \\
\hline Anadara diluvii (LAMARCK, 1805) & & & & & $\mathrm{X}$ \\
\hline Anadara pectinata (BRoccHI, 1814) & & & $X$ & & $X$ \\
\hline Striarca lactea (LINNAEUS, 1758) & $X$ & & & & $X$ \\
\hline Glycymeris glycymeris (LINNAEUS, 1758) & $\mathrm{X}$ & $X$ & $\mathrm{X}$ & $X$ & $\mathrm{X}$ \\
\hline Ostrea edulis LINNAEUS, 1758 & $\mathrm{X}$ & $\mathrm{X}$ & $\mathrm{X}$ & $\mathrm{X}$ & $X$ \\
\hline \multicolumn{6}{|l|}{ Neopycnodonte cochlear (PoLI, 1795) } \\
\hline Atrina fragilis (PENNANT, 1777) & $X$ & & & $\mathrm{X}$ & \\
\hline Pteria hirundo (LINNAEUS, 1758) & $X$ & & & & \\
\hline $\begin{array}{l}\text { Aequipecten opercularis (Linnaeus, } \\
\text { 1758) }\end{array}$ & & $X$ & & $\mathrm{X}$ & \\
\hline Flexopecten flexuosus (PoLI, 1795) & & & & $X$ & $X$ \\
\hline Pecten benedictus LAMARCK, 1819 & $\mathrm{X}$ & $\mathrm{X}$ & & $\mathrm{X}$ & $X$ \\
\hline Palliolum excisum (BRONN, 1831) & $\mathrm{X}$ & $X$ & & $\mathrm{X}$ & $\mathrm{X}$ \\
\hline Hinnites crispus (BROccHI, 1814) & & & & 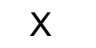 & $X$ \\
\hline \multicolumn{6}{|l|}{ Hinnites ercolanianus CoccoNI, 1873} \\
\hline Mimachlamys varia (Linnaeus, 1758) & & $X$ & $X$ & $X$ & $X$ \\
\hline Talochlamys multistriata (PoLI, 1795) & $X$ & & $\mathrm{X}$ & & $X$ \\
\hline \multicolumn{6}{|l|}{ Similipecten similis (LASKEY, 1811) } \\
\hline \multicolumn{6}{|l|}{$\begin{array}{l}\text { Heteranomia squamula (LINNAEUS, } \\
\text { 1758) }\end{array}$} \\
\hline \multicolumn{6}{|l|}{ Pododesmus squama (GMELIN, 1791) } \\
\hline Lima lima (LINNAEUS, 1758) & & & & & $X$ \\
\hline \multicolumn{6}{|l|}{$\begin{array}{l}\text { Limaria loscombi (G.B. SoWERBY Io, } \\
\text { 1823) }\end{array}$} \\
\hline Limaria tuberculata (OLIVI, 1792) & $\mathrm{X}$ & & & & $X$ \\
\hline
\end{tabular}

They occur with a diverse fossil content of macrofaunal elements, including small scleractinian corals, branched and incrusting bryozoans, a terebratulid brachiopod, serpulid worms, balanoids (Ferreira et al., 2019) and decapod crustaceans, spatangoid and epifaunal echinoids, and small fishes (Nolf and Silva, 1997). The microfauna is also very abundant, including benthic and planktonic foraminifera, ostracods and dinoflagellates (Vieira et al., 2006). These assemblages contain many elements that suggest a location in the subtropical Mean Monthly Sea Surface Temperature (MMSST), in a position close to the seashore and slightly protected from the direct influence of the open ocean (e.g. Silva and Landau, 2009).
One of the results of the present study is the increase of the number of bivalve species of the Carnide area from 48 to more than 90 . The bivalve diversity of Vale do Freixo is higher than other analogous fossil assemblages of the Estremadura mountain ranges, such as those studied by Dollfus and Cotter (1909), with 78 species belonging to 27 families. Nevertheless, a new sampling and taxonomical review will be required for these faunas and their collections conserved at the Geological Museum, in Lisbon. The number of Pliocene bivalve species known for the Mondego Basin also increase to 115 as a result of this study. 
TABLE 2. Bivalvia species from Vale do Freixo and their occurrence in other Beira Litoral and Estremadura localities. Subclass Autobranchia, Infraclass Heteroconchia. $\mathrm{CN}=$ Carnide ( $\mathrm{b}=$ Igreja de Carnide, $\mathrm{c}=$ Vale da Bouchada, $\mathrm{d}=\mathrm{Vale}$ Farpado, e= Vale da Cabra); MR= Monte-Real; PM= S. Pedro de Moel ( $\mathrm{g}=$ Mina, $\mathrm{h}=$ Senhora da Vitória); NZ= Nazaré (i= Famalicão, j= Bom Jesus, k= Salir do Porto) and CR= Caldas da Rainha (l= Nadadouro, m= Casal do Negreiro, n= Águas Santas); see Figure 1 for the localities. Data from: Cox, 1941; Choffat, 1889; Dollfus and Cotter, 1909; Manuppella et al., 1978; Pimentel, 2018; Pimentel et al., 2018; Teixeira and Zbyszewski, 1951; Zbyszewski, 1959; Zbyszewski and Moitinho de Almeida, 1960; Zbyszewski et al., 1961

\begin{tabular}{|c|c|c|c|c|c|}
\hline Vale do Freixo (Carnide) & $\begin{array}{l}\mathrm{CN} \\
(\mathrm{b}-\mathrm{e})\end{array}$ & $\begin{array}{c}\text { MR } \\
\text { (f) }\end{array}$ & $\begin{array}{l}\text { PM } \\
(g-h)\end{array}$ & $\begin{array}{c}N Z \\
(\mathrm{i}-\mathrm{k})\end{array}$ & $\begin{array}{c}\text { CR } \\
(I-n)\end{array}$ \\
\hline Astarte fusca (PoLI, 1791) & $\mathrm{x}$ & & & & $\mathrm{X}$ \\
\hline Digitaria digitaria (LINNAEUS, 1758) & $x$ & & $\mathrm{x}$ & & $x$ \\
\hline \multicolumn{6}{|l|}{ Goodallia triangularis (MONTAGU, 1803) } \\
\hline Cardita calyculata (LINNAEUS, 1758 ) & & & & & $\mathrm{x}$ \\
\hline Cardites antiquatus (LINNAEUS, 1758) & & & & & $\mathrm{x}$ \\
\hline Megacardita striatissima (MAYER, 1868) & $\mathrm{x}$ & $\mathrm{x}$ & & & $\mathrm{x}$ \\
\hline \multicolumn{6}{|l|}{ Centrocardita aculeata (PoLI, 1795) } \\
\hline Scalaricardita scalaris (SOWERBY, 1825) & $\mathrm{x}$ & & & & $\mathrm{x}$ \\
\hline Lucinoma borealis (LINNAEUS, 1767) & $\mathrm{x}$ & & & & \\
\hline \multicolumn{6}{|l|}{ Megaxinus transversus (BRONN, 1831) } \\
\hline \multicolumn{6}{|l|}{ Loripinus fragilis (PHILIPPI, 1836) } \\
\hline Pharus legumen (LINNAEUs, 1758) & $\mathrm{x}$ & & & $\mathrm{x}$ & $\mathrm{x}$ \\
\hline \multicolumn{6}{|l|}{ Phaxas pellucidus (PENNANT, 1777) } \\
\hline Ensis siliqua (LINNAEUs, 1758) & $\mathrm{x}$ & $\mathrm{x}$ & & & $\mathrm{x}$ \\
\hline \multicolumn{6}{|l|}{ Hiatella rugosa (LINNAEUs, 1767) } \\
\hline Procardium diluvianum (LAMARCK, 1819) & $\mathrm{x}$ & & & & \\
\hline Acanthocardia aculeata (LINNAEUS, 1758) & & $x$ & $\mathrm{x}$ & & $\mathrm{x}$ \\
\hline Papillicardium papillosum (PoLI, 1791) & & & & & $\mathrm{x}$ \\
\hline \multicolumn{6}{|l|}{ Parvicardium scriptum (BUCQUOY, } \\
\hline \multicolumn{6}{|l|}{ DAUTZENBERG AND DoLLFus, 1892) } \\
\hline Laevicardium crassum (GMELIN, 1791) & $\mathrm{x}$ & & & & \\
\hline $\begin{array}{l}\text { Europicardium multicostatum (BROCCHI, } \\
\text { 1814) }\end{array}$ & $\mathrm{x}$ & & & & \\
\hline Arcopagia corbis (BRonN, 1831) & $\mathrm{x}$ & $\mathrm{x}$ & $\mathrm{x}$ & & $\mathrm{x}$ \\
\hline Arcopagia crassa (PENNANT, 1777) & $\mathrm{x}$ & & & & $\mathrm{x}$ \\
\hline Gastrana fragilis (LINNAEUS, 1758) & & & $\mathrm{x}$ & $\mathrm{x}$ & $\mathrm{x}$ \\
\hline Macomopsis elliptica (BROCCHI, 1814) & $\mathrm{x}$ & & & & $\mathrm{x}$ \\
\hline \multicolumn{6}{|l|}{ Bosemprella incarnata (LINNAEUS, 1758) } \\
\hline \multicolumn{6}{|l|}{ Oudardia compressa (BROCCHI, 1814) } \\
\hline Peronidia albicans (GMELIN, 1791) & & & & & $x$ \\
\hline Donax variegatus (GMELIN, 1791) & $\mathrm{x}$ & & & & \\
\hline \multicolumn{6}{|l|}{ Gari depressa (PENNANT, 1777) } \\
\hline \multicolumn{6}{|l|}{ Gari tellinella (LAMARCK, 1818) } \\
\hline Gari fervensis (GMELIN, 1791) & $\mathrm{x}$ & & & & \\
\hline Abra alba (W. WooD, 1802) & & & & & $\mathrm{x}$ \\
\hline Abra prismatica (MONTAGU, 1808) & $x$ & & & & \\
\hline Chama gryphoides LINNAEUS, 1758 & & & $\mathrm{x}$ & & \\
\hline Mactra stultorum (LINNAEUS, 1758) & $\mathrm{x}$ & & & & $\mathrm{x}$ \\
\hline Spisula subtruncata (DA COSTA, 1778) & $\mathrm{x}$ & & $\mathrm{x}$ & & $\mathrm{x}$ \\
\hline Spisula solida (LINNAEUS, 1758) & $\mathrm{x}$ & $\mathrm{x}$ & & & $\mathrm{x}$ \\
\hline Lutraria lutraria (LINNAEUS, 1758) & & $x$ & & & $\mathrm{x}$ \\
\hline \multicolumn{6}{|l|}{ Cardilia michelottii DESHAYES, 1844} \\
\hline \multicolumn{6}{|l|}{ Diplodonta rotundata (MONTAGU, 1803) } \\
\hline Callista chione (LINNAEUS, 1758) & $\mathrm{x}$ & & $\mathrm{x}$ & & $\mathrm{x}$ \\
\hline Chamelea gallina (LINNAEUS, 1758) & $\mathrm{x}$ & & & & \\
\hline $\begin{array}{l}\text { Circomphalus foliaceolamellosus } \\
\text { (DILLWYN, 1817) }\end{array}$ & $\mathrm{x}$ & $x$ & & & \\
\hline Clausinella fasciata (DA COSTA, 1778) & $\mathrm{x}$ & & $\mathrm{x}$ & & $\mathrm{x}$ \\
\hline
\end{tabular}


TABLE 2. Continued

\begin{tabular}{|c|c|c|c|c|c|}
\hline Vale do Freixo (Carnide) & $\begin{array}{c}\text { CN } \\
\text { (b-e) }\end{array}$ & $\begin{array}{c}\text { MR } \\
\text { (f) }\end{array}$ & $\begin{array}{l}\text { PM } \\
(g-h)\end{array}$ & $\begin{array}{c}N Z \\
(\mathrm{i}-\mathrm{k})\end{array}$ & $\begin{array}{l}\text { CR } \\
\text { (I-n) }\end{array}$ \\
\hline Dosinia lupinus (LINNAEUS, 1758) & $\mathrm{x}$ & & & & \\
\hline \multicolumn{6}{|l|}{ Gouldia minima (MONTAGU, 1803) } \\
\hline \multicolumn{6}{|l|}{ Pitar rudis (PoLI, 1795) } \\
\hline Tapes vetula (BASTEROT, 1825) & $\mathrm{x}$ & & & & $x$ \\
\hline Timoclea ovata (PENNANT, 1777) & $x$ & & & & $\mathrm{X}$ \\
\hline Venus casina LINNAEUS, 1758 & $\mathrm{x}$ & & & & \\
\hline Venus verrucosa LINNAEUS, 1758 & & & $x$ & $\mathrm{X}$ & $x$ \\
\hline \multicolumn{6}{|l|}{ Spaniorinus reconditus (FISCHER, 1872) } \\
\hline Scacchia oblonga (PHILIPPI, 1836) & & & & & $\mathrm{X}$ \\
\hline Corbula gibba (OLIVI, 1792) & $\mathrm{X}$ & & & & \\
\hline Corbula revoluta (BROCCHI, 1814) & & & & & \\
\hline
\end{tabular}

Comparing the Pliocene bivalves of Vale do Freixo with similar assemblages reported from basins not faraway, as the Estepona Basin (Vera-Peláez and Lozano-Francisco, 2001) and Vélez Málaga area (Malaga Basin, southern Spain), despite not being entirely synchronous, range to 173 species and 46 families of bivalve molluscs (Lozano-Francisco, 1997, 1998; Vera-Peláez et al., 1995). This assemblage represents a variety of facies, including deeper water deposits, unlike those of the Mondego Basin, in Portugal.

On the southern Atlantic coast of the Iberian Peninsula, the Guadalquivir Basin (Huelva, SW of Spain) records more than 120 species (e.g. Andrés 1983, 1984, 1985, 1987, 1989; Andrés and Porta, 1987; Castano et al., 1988; GonzálezDelgado, 1979; González-Delgado et. al., 1995; Landau, 1984; Lozano-Francisco and Landau, 1999) and 34 families (González-Delgado et al., 1984) of bivalve molluscs.

The 178 species of bivalve molluscs from the Redonian (Pliocene) of the Loire Basin, northwest of France, cited by Lauriat-Rage (1981), despite the strategic geographical position on the edge of the Pliocene French-Iberian Bioprovince, it is not easy for us to establish a general comparison given their heterochronic character from the upper Miocene to the Pleistocene. Only the Redonian sites in the Nantes area and Vendée, Loire-Atlantique, would be of early Pliocene age (e.g. Brault et al., 2004; van Dingenen et. al., 2015) and could be correlative in some extent to the Vale do Freixo assemblage. In addition, Landau et al. (2020) considered the provincialism of the Zanclean (Pliocene) gastropods, including those of the Portuguese fossil site, enough to create a distinct Ligerian molluscan subprovince. Other Britany Redonian localities would be of Miocene age (e.g. Brébion, 1964; Dollfus, 1900, 1904; Mercier et al., 2000; Monegatti and Raffi, 2010; Néraudeau et al., 2002, 2003).

According to ter Poorten and la Perna (2017), the Early Pliocene to Early Pleistocene large cardiid Procardium diluvianum occurred from the Atlantic Guadalquivir
Basin to the eastern Mediterranean. This range area probably extended southwards, along the west coast of Africa. We include Vale do Freixo and the Mondego Basin in the Atlantic margin of West-Central Portugal as the northernmost known area of distribution for this genus, during the Pliocene.

Cardilia michelottii DESHAYES, 1844 has been cited in the Italian Miocene (Doderlein, 1862), Pliocene (e.g. Bronn, 1848; Chirli, 2015; Deshayes, 1844; Fischer, 1861; Manzoni, 1868, 1870; d'Orbigny, 1852; Pantanelli, 1892; Pictet, 1855; Sacco, 1889, 1901; Signorelli and Raven, 2018; Sismonda, 1847) and Pleistocene (Cerulli-Irelli, 1909; Clerici, 1888; Ponzi and Meli, 1887). The genus Cardilia has also been mentioned in the list of Pliocene bivalves from Huelva (Spain) - C. michelottii (Landau, 1984) and C. cf. sulcata (Galán Ávila et al., 2002). A single specimen was found in Vale do Freixo (Pimentel, 2018; Pimentel et al., 2018, 2019) with a morphology close to $C$. michelottii from the Italian Neogene (e.g. Sacco, 1901, pg.: 32; pl. VI, figs. 26-30; Cerulli-Irelli, 1909, pg.: 145 [161], pl. XVI [XXVI], fig. 6; Chirli, 2015, pg.: 83, pl.19, figs. 7-10). However, there are a few morphological differences to note, including the less circular outline of the valve, with the anterior and posterior margins less concave and the umbo-paleal diameter much larger than the anteroposterior (Pimentel et al., 2019). More specimens and following studies on the Italian, Huelva and Vale do Freixo valves would be necessary to solve this puzzle, and to verify if an Atlantic Pliocene species of this family does exist, close to the Mediterranean C. michelottii.

The original species name Scintilla recondita P. FISCHER, 1872, has been assigned to genus Sportella DESHAYES, 1858 (e.g. Monterosato, 1872; Locard, 1886; Sacco, 1899; Cossignani and Ardovini, 2011), and Spaniorinus DALL, 1900b (e.g. Andrés, 1987; González-Delgado et al., 1984). All specimens studied here correspond to those figured by Chirli (2015) which lack the fine radial ornamentation 
defined in the original description and figured by Huber (2015, pg.: 162). This difference led us to classify the specimens of Vale do Freixo as Spaniorinus ambiguus (NYST AND WESTENDORP, 1839) in previous works (Pimentel, 2018; Pimentel et al., 2018). However, its elliptical outline and dimensions match with Spaniorinus reconditus (P. FISCHER, 1872) referenced as well in the Pliocene of Huelva, in southern Spain (e.g. González-Delgado et. al., 1984). In addition, the description of the hinge in the genus Sportella in Deshayes (1858, pg.: 593) matches that of our specimens. It seems imperative to revise and clarify these specimens from the Iberian Pliocene.

\section{CONCLUSIONS}

The Vale do Freixo fossil site, in the West Portuguese Margin of Iberia, yeilded the most diverse and wellpreserved marine faunal assemblages of Pliocene age reported in the area.

Twenty-three of the reported Bivalvia species were unknown in the Portuguese Pliocene (Ennucula laevigata, Gregariella sp., Neopycnodonte cochlear, Hinnites ercolanianus, Heteranomia squamula, Pododesmus squama, Limaria loscombi, Goodallia triangularis, Centrocardita aculeata, Megaxinus transversus, Loripinus fragilis, Phaxas pellucidus, Hiatella rugosa, Parvicardium scriptum, Bosemprella incarnata, Oudardia compressa, Gari tellinella, Cardilia michelottii, Diplodonta rotundata, Gouldia minima, Pitar rudis, Spaniorinus reconditus and Corbula revoluta). Moreover, twenty species are reported for the first time in the Pliocene of the Carnide area, in Pombal, in addition to the species mentioned above (Modiolus sp., Arca tetragona, Anadara diluvii, Anadara pectinata, Aequipecten opercularis, Flexopecten flexuosus, Hinnites crispus, Mimachlamys varia, Lima lima, Cardita calyculata, Cardites antiquatus, Acanthocardia aculeata, Papillicardium papillosum, Gastrana fragilis, Peronidia albicans, Gari depressa, Abra alba, Chama gryphoides, Lutraria lutraria and Scacchia oblonga). Consequently, the diversity of Pliocene bivalves in the Mondego Basin has increased to 115 species.

The Mondego Basin should correspond to the northernmost Piacenzian occurrence area for thermophilic bivalve molluscs such as Cardilia michelottii and Procardium diluvianum. Further studies on cardiliidae specimens from Huelva and Vale do Freixo would be needed to verify that a distinct Pliocene cardiliid species of Atlantic distribution does exist, althrough close to the Mediterranean Cardilia michelottii. It would be also convenient to revise the taxonomic status of the Spaniorinus specimens from the Iberian Pliocene. The results of the present work on the
Pliocene bivalves of Portugal emphasize the importance of the Mondego Basin and the Estremadura mountain ranges, in the biogeographic knowledge of the Atlantic marine faunas of Europe, and their relations with the Mediterranean and North-African warmer ones.

\section{ACKNOWLEDGMENTS}

We are especially thankful to Prof. la Perna and the anonymous reviewers for their helpful suggestions, corrections and comments, which resulted in a considerable improvement of the manuscript. We are grateful to GeoBioTec (UIDB/04035/2020) for its financial support. Pedro Callapez thanks the funding provided by CITEUC - Centre for Earth and Space Research of the University of Coimbra, project UID/Multi/00611/2020 of FCT (Portugal), and the sponshorship of PALEOIBERICA, Grupo de Investigación Consolidado de la Universidad de Alcalá (COD-824).

\section{REFERENCES}

Abbott, R.T., 1954. American Seashells. Toronto, Van Nostrand Reinhold Co., 541pp.

Adams, C.B., 1847. Catalogue of the genera and species of Recent shells in the collection of C.B. Adams. Middlebury, Justus Cobb, 32pp.

Adams, H., Adams, A., 1856-1858. The genera of Recent Mollusca arranged according to their organisation. London, Van Voorst, vol. 1, 484pp; vol. 2, 661pp.

Andrés, I., 1983. Estudio malacológico (Clase Bivalvia) del Plioceno marino de Bonares (Huelva). Resumen de Tesis Doctoral. Salamanca, Ediciones Universidad de Salamanca, 38pp.

Andrés, I., 1984. Los Veneridae (Bivalvia) en el Plioceno de Bonares. Stvdia Geologica Salmanticense, 19, 101-131.

Andrés, I., 1985. Los Tellinacea (Bivalvia) en el Plioceno de Bonares (Huelva). Stvdia Geologica Salmanticense, 20, 79-113.

Andrés, I., 1987. Los Heterodonta (Bivalvia) en el Plioceno de Bonares (Huelva). Stvdia Geologica Salmanticense, 24, 83-149.

Andrés, I., Porta, J., 1987. La distribución de los Pectinidae en el Neógeno de Huelva. Datos preliminares. In: Civis, J. (ed.). Paleontología del Neógeno de Huelva. Salamanca, Ediciones de la Universidad de Salamanca, 143-151.

Andrés, I., 1989. Estudio sistemático de los bivalvos Palaeotaxodonta y Pteriomorphia (Arcoida, Mytiloida) del Plioceno de Bonares (Huelva). Stvdia Geologica Salmanticense, 26, 317-353.

de Basterot, M., 1825. Mémoire géologique sur les environs de Bordeaux. Première partie, contenant les observations générales sur les mollusques fossiles, et la description particulière de ceux qu'on rencontre dans ce bassin. Paris, Joseph Tastu, 100pp. 
Beurlen, K., 1944. Beiträge zur Stammesgeschichte der Muscheln. Mathematisch-Naturwissenschaftlichen Abteilung der Bayerischen Akademie der Wissenschaften zu München, Sitzungsberichte, 1-2, 133-145.

Bieler, R., Carter, J.G., Coan, E.V., 2010. Classification of Bivalve Families. In: Bouchet, P., Rocroi, J.-P. (eds.). Nomenclator of Bivalve Families. Malacologia, 52(2), 113-133.

Bieler, R., Mikkelsen, P.M., Collins, T.M., Glover, E.A., González, V.L., Graff, D.L., Harper, E.M., Healy, J., Kawauchi, G.Y., Sharma, P.P., Staubach, S., Strong, E.E., Taylor, J.D., Tëmkin, I., Zardus, J.D., Clark, S., Guzmán, A., McIntyre, E., Sharp, P, Giribet, G., 2014. Investigating the Bivalve Tree of Life - an exemplar-based approach combining molecular and novel morphological characters. Invertebrate Systematics, 28, 32-115.

de Blainville, H.-M.D., 1814. Mémoire sur la classification méthodique des animaux mollusques, et établissement d'une nouvelle considération pour y parvenir. Bulletin des Sciences par la Société Philomatique de Paris, Zoologie, 1814, 175-180.

Bosc, L.A.G., 1801. Histoire naturelle des coquilles, contenant leur description, les moeurs des animaux qui les habitent et leurs usages. Paris, Deterville, vol. 1, 343pp; vol. 2, 330pp; vol. 3, 292pp; vol. 4, 280pp; vol. 5, 255pp.

Brault, N., Bourquin, S., Guillocheau, F, Dabard, M.-P., Bonnet, S., Courville, P., Estéoule-Choux, J., Stepanoff, F, 2004. Mio-Pliocene to Pleistocene paleotopographic evolution of Brittany (France) from a sequence stratigraphic analysis: relative influence of tectonics and climate. Sedimentary Geology, 163, 175-210.

Brébion, P., 1964. Les Gastéropodes du Redonien et leur signification. Thèse d'État. France, Universitè Paris, 775pp.

Brébion, P., 1971. Les Gastéropodes et Scaphopodes $\mathrm{du}$ Pliocène portugais. Remarques stratigrafiques et paléogéographiques. Boletim da Sociedade Geológica de Portugal, 17(2-3), 129-138.

Brébion, P., 1974. Nouvelle contribution à l'étude des gastéropodes du Pliocène portugais. Comunicações dos Serviços Geológicos de Portugal, 58, 151-160.

Brocchi, G., 1814. Conchiologia fossile subapennina, con osservazioni geologiche sugli Apennini e sul suolo adiacente. Milano, Dalla Stamperia Reale, 2, 712pp.

Bronn, H.G., 1831. Italiens Tertiär-Gebilde und deren organische Einschlusse. Heidelberg, 176pp.

Bronn, H.G., 1848-1849. Index Palaeontologicus oder Übersicht der bis Jetzt Bekannten Fossilen Organismen, bearbeitet unter Mitwirkung der Herren Prof. H.R. Göppert and Herm. von Meyer, bearbeitet von Dr. H.G. Bronn. A. Nomenclator Palaeontologicus, in Alphabetischer Ordnung. Stuttgart, Erste Hälfte, A-M. Schweizerbart'sche Verlagsbuchhandlung, 775pp.

Bronn, H.G., 1862. Die Klassen und Ordnungen der Weichthiere (Malacozoa). Wissenschaftlich Dargestellt in Wort und Bild, Bd. 3, Abt. 1 (Malacozoa Acephala). Winter, Leipzig and Heidelberg, 518pp.

Brown, T., 1827. Illustrations of the conchology of Great Britain and Ireland. Drawn from nature. Edinburgh and S. Highley, London, W.H. Lizars and D. Lizars, 144pp.
Brugnone, G., 1880. Le conchiglie plioceniche selle vicinaze di Caltanisetta. Bolletino Societá Malacologia Italiana, 6, 85-158.

Bruguière, J.G., 1789-1792. Encyclopédie méthodique ou par ordre de matières. Pancoucke, Paris, Histoire naturelle des vers, $1.757 \mathrm{pp}$.

Bruguière, J.G., 1791-1797. Tableau encyclopédique et méthodique des trois règnes de la nature. Vers, coquilles, mollusques et polypiers. Paris, Panckoucke, Part 7 [1791]: Tome 1, 1-83, pls. 1-95. Paris, Panckoucke, Part 10 [1792]: Tome 1, 85-132; Tome 2, pls. 96-189. Paris, H. Agasse, Part 19 [1797]: pls. 190-286.

Bucquoy, E., Dautzenberg, Ph., Dollfus, G., 1887-1898. Les Mollusques marins du Roussillon. Vol. 2 - Pèlècypodes. Paris, Baill and Fils, 884pp.

Cachão, M., 1989. Contribuição para o estudo do Pliocénico marinho Português. Dissertação apresentada no âmbito das Provas de Aptidão Pedagógica e Capacidade Científica. Unpublished MSc dissertation. Faculdade de Ciências da Universidade de Lisboa, 210pp.

Cachão, M., 1990. Posicionamento Biostratigráfico da Jazida Pliocénica de Carnide (Pombal). Gaia, 2, 11-16.

Canapa, A., Schiaparelli, S., Marota, I., Barucca, M., 2003. Molecular data from the 16S rRNA gene for the phylogeny of Veneridae (Mollusca: Bivalvia). Marine Biology, 142, 1125-1130.

Cardoso, J.L., 1984. O Pliocénico marinho de Caldas da Rainha e de Pombal. Sedimentologia e Micropaleontologia. Enquadramento Paleogeográfico e Paleoecológico. In: Volume d'hommage au géologue G. Zbyszewski. Paris, Recherche sur les Civilisations, 155-201.

Carter, J.G., Campbell, D.C., Campbell, M.R., 2000. Cladistic perspectives on early bivalve evolution. In: Harper, E.M., Taylor, J.D., Crame, J.A. (eds.). The Evolutionary Biology of the Bivalvia. The Geological Society of London, 117 (Special Publications), 177, 47-79.

Carter, J.G., Altaba C.R., Anderson, L.C., Araujo, R., Biakov, A.S., Bogan, A.E., Campbell, D.C., Campbell, M., Jin-hua, C., Cope, J.C.W., Delvene, G., Dijkstra, H.H., Zong-jie, F,, Gardner, R.N., Gavrilova, V.A., Goncharova, I.A., Harries, P.J., Hartman, J.H., Hautmann, M., Hoeh, W.R., Hylleberg, J., Bao-yu, J., Johnston, P., Kirkendale, L., Kleemann, K., Koppka, J., Kř̌ž, J., Machado, D., Malchus, N., MárquezAliaga, A., Masse, J.-P., McRoberts, C.A., Middelfart, P.U., Mitchell, S., Nevesskaja, L.A., Özer, S., Pojeta Jr., J., Polubotko, I.V., Pons, J.M., Popov, S., Sánchez, T., Sartori, A.F, Scott, R.W., Sey, I.I., Signorelli, J.H., Silantiev, V.V., Skelton, P.W., Steuber, T., Waterhouse, J.B., Wingard, G.L., Yancey, T., 2011. A synoptical classification of the Bivalvia (Mollusca). Paleontological Contributions, 4, 1-47.

Carvalho, G.S., Colom, G., 1954. Contribuição para o estudo da micropaleontologia dos depósitos detríticos pliocénicos de Portugal. Memórias e Notícias, 37, 37-60.

Carvalho, A.M.G., 1961. Note sur les Bryozoaires du Pliocène de Pombal. Boletim da Sociedade Geológica de Portugal, $14,95-103$. 
Carvalho, A.M.G., 1971. Briozoários do Terciário Português (Cheislostomata) do Neogénico da Orla Ocidental. Lisboa, Publicações do Centro de Estudos de Estratigrafia e Geologia, Faculdade de Ciências de Lisboa, 176pp.

Carvalho, M., 1998. Estudo preliminar do Plio-Quaternário do Baixo Mondego. Sector Monte Redondo-Pombal. Actas do V Congresso Nacional de Geologia. Comunicações do Instituto Geológico e Mineiro, 84(1), 173-176.

Carvalho, M., Callapez, P.M., Ferreira Soares, A., 2005a. First record of Similipecten similis (Laskey, 1811) (Mollusca, Bivalvia, Pectinacea) in the Pliocene of Portugal. Portugala, 5, 29-30.

Carvalho, M., Callapez, P.M., Ferreira Soares, A., Gomes, H., Oliveira, M., 2005b. Infraspecific variation of Megacardita striatissima (Cailliaud, in Mayer, 1868) (Mollusca, Bivalvia, Carditoidea) in the Pliocene of Pombal (West Central Portugal). Portugala, 5, 29.

Carvalho, M., Ferreira Soares, A., Callapez, P.M., 2005c. Evolução sedimentar Plio-Plistocénica na região do Baixo Mondego: sector Pombal-Monte Redondo-Soure (Beira Litoral, Portugal). Actas do VII Congresso Nacional de Geologia. Estremoz, Junho/Julho de 2006, Sociedade Geológica de Portugal, 625-628.

Castano, M.J., Civis, J., Gonzaléz-Delgado, J.A., 1988. Los molluscos del Plioceno de la Palma del Condado y Moguer (Huelva). Aproximación paleoecológica. Iberus, 8(2), 173-186.

Cerulli-Irelli, S., 1909. Fauna malacologica mariana. Parte terza e appendice: Cyrenidae, Donacidae, Psammobiidae, Solenidae, Mesodesmatidae, Mactridae, Cardiiae, Myidae, Corbulidae, Glycymeridae, Gastrochaenidae, Thyasiridae, Diplodontidae, Lucinidae, Tellinidae, Scrobiculariidae, Cuspidariidae, Pandoridae, Verticordiidae, Lyonsidae, Anatinidae, Pholadomydae, Clavagellidae. Palaeontographia Italica, 15, 125-214.

Chavan, A., 1969. Superfamily Carditacea. In: Moore, R.C. (ed.). Treatise on Invertebrate Paleontology. Part N, vol. 1-2, Mollusca 6, Bivalvia. Boulder and Lawrence, Geological Society of America and University of Kansas, 543-561.

Chirli, C., 2014. Malacofauna Pliocenica Toscana. Bivalvia: Pteriomorphia Beurlen, 1894, vol. 10. Firenze, Author's Edition, 224pp.

Chirli, C., 2015. Malacofauna Pliocenica Toscana. Bivalvia: Heteroconchia Hertwig, 1895, vol. 11. Firenze, Author's Edition, 233pp.

Chirli, C., 2016. Malacofauna Pliocenica Toscana. Bivalvia: Heteroconchia Hertwig, 1895 - Protobranchia Pelsener, 1889, vol. 12. Firenze, Author's Edition, 211pp.

Choffat, P., 1889. Observations sur le Pliocéne du Portugal. Bulletin de la Société Belge de Géologie, de Paléontologie et d'Hydrologie, 3, 119-123.

Clerici, E., 1888. Sulla Corbicula fluminalis dei dintorni di Roma e sui fossili che l'accompagnano. Bullettino della Società Geologica Italiana, 7, 105-127.
Cocconi, G., 1873. Enumerazione sistematica dei molluschi miocenici e pliocenici di Parma e Piacenza. Memorie dell'Adademia delle Scienze dell'Istituto di Bologna, 3, 1-372.

Conrad, T.A., 1862. Descriptions of new genera, subgenera and species of Tertiary and Recent shells. Proceedings of the Academy of Natural Sciences, 14, 284-291.

Cossignani, T., Ardovini, R., 2011. Malacologia mediterrânea. Ancona, Linformatore Piceno, 536pp.

Cossmann, M., Peyrot, A., 1909-1914. Conchologie néogénique de l'Aquitaine. Pélécypodes. Bordeaux, A. Saugnac, vol. 1, 718pp; vol. 2, 496pp.

da Costa, E.M., 1778. Historia Naturalis Testaceorum Britanniae, or, The British Conchology. Millan, White, London, Elmsley and Robson, 254pp.

Cox, L.R., 1936. Pliocene Mollusca from Portugal. Memórias e Notícias, 9, 47-75.

Cox, L.R., 1941. New Species of Gastropoda from the Pliocene of Portugal. Memórias e Notícias, 10, 7-12.

Cunha, P.P., 1992. Estratigrafia e sedimentologia dos depósitos do Cretácico Superior e Terciário de Portugal Central, a leste de Coimbra. Unpublished PhD Thesis, Universidade de Coimbra, 262pp.

Cunha, P.P., Barbosa, B.P., Pena dos Reis, R., 1993. Synthesis of the Piacenzian onshore record, between the Aveiro and Setúbal parallels (Western Portuguese margin). Ciências da Terra, 12, $35-43$.

Cunha, P.P., Martins, A.A., Pais, J., 2008. O estudo do Cenozóico em Portugal continental - "estado da arte" e perspectivas futuras. In: Callapez, P.M., Rocha, R. B., Cunha L., Marques, J. F., Dinis, P. M. (eds.). A Terra conflitos e ordem, Homenagem ao Professor Ferreira Soares. Coimbra, 101-110.

Cunha, P.P, Pais, J., Legoinha, P., 2009. Evolução geológica de Portugal continental durante o Cenozóico - sedimentação aluvial e marinha numa margem continental passiva (Ibéria ocidental). Oviedo, Dezembro de 2009, VI Simposio sobre el Margen Ibérico Atlántico MIA09, 1120.

Cunha, P.P., 2019. Cenozoic Basins of Western Iberia: Mondego, Lower Tejo and Alvalade Basins. In: Quesada, C., Oliveira, J.T. (eds.). The Geology of Iberia: A Geodynamic Approach. Springer Nature Switzerland, 4. 105-130.

Dall, W.H., 1889. On the hinge of pelecypods and its development, with an attempt toward a better subdivision of the group. American Journal of Science, ser. 3, 38(228), 445-462.

Dall, W.H., 1900a. Synopsis of the family Tellinidae and of the North American species. Proceedings of the United States National Museum, 23, 285-326.

Dall, W.H., 1900b. Contributions to the Tertiary fauna of Florida, with especial reference to the Miocene silex-beds of Tampa and the Pliocene beds of the Calooshatchie River. Transactions of the Wagner Free Institute of Science, 3(5), 949-1218.

Dall, W.H., 1901. Synopsis of the Lucinacea and of the American species. Proceedings of the United States National Museum, 23, 779-833.

Dall, W.H., 1908. Reports on the dredging operations off the west coast of Central America to the Galapagos, to the West coast of 
Mexico, and in the Gulf of California, in charge of Alexander Agassiz, carried on by the U.S. Fish Commission steamer "Albatross," during 1891, Lieut. Commander Z.L. Tanner, U.S.N., commanding. XXXVII. Reports on the scientific results of the expedition to the eastern tropical Pacific, in charge of Alexander Agassiz, by the U.S. Fish Commission steamer "Albatross", from October, 1904, to March, 1905, lieut. commander L.M. Garrett, U.S.N., commanding. XIV. The Mollusca and the Brachiopoda. Museum of Comparative Zoology, Harvard University, Bulletin 43(6), 205-487.

Davies, A.M., 1935. Tertiary Faunas. A Textbook for Oilfield Palaeontologists and Students of Geology, vol. 1. The Composition of Tertiary Faunas. London, Thomas Murby and Co., 406pp.

Defrance, F., 1821. Dictionnaire des sciences naturelles, vol. 20. Strasbourg, Levrault, 572pp.

Dell'Angelo, B., Silva, C.M., 2003. Polyplacophora from the Pliocene of Vale do Freixo: Central-West Portugal. Bollettino Malacologico, 39(1-4), 7-16.

Deshayes, G.P., Milne Edwards, H., 1835. Histoire des Mollusques. In: de Lamarck, J.B.P.A. (ed.). Histoire naturelle des animaux sans vertèbres, vol. 6. Paris, Jean-Baptiste Baillière et fils, 600pp.

Deshayes, G.P., 1844. G. Cardilia Deshayes. Magasin de Zoologie, d'Anatomie Comparée et de Paléontologie, sér. 2, 6(8), 1-8.

Deshayes, G.P., 1856-1866. Description des animaux sans vertèbres découverts dans le bassin de Paris pour servir de supplément à la Description des coquilles fossiles des environs de Paris comprenant une revue générale de toutes les espèces actuellement connues. Mollusques acéphales Dymiaires, vol. 1. Paris, Jean-Baptiste Baillière et fils, 912pp.

Dillwyn, L.W., 1817. A descriptive catalogue of recent shells, arranged according to the Linnean method; with particular attention to the synonymy. London, John and Arthur Arch, vol. 1, 1-580; vol. 2, 581-1092 + index (29pp.)

van Dingenen, F, Ceulemans, L., Landau, B.M., Silva, C.M., 2015. The family Nassariidae (Gastropoda: Buccinoidea) from the late Neogene of northwestern France. Cainozoic Research, 15(1-2), 75-122.

Diniz, F., Silva, C.M., Cachão, M., 2016. O Pliocénico de Pombal (Bacia do Mondego, Portugal Oeste): Biostratigrafia, Paleoecologia e Paleobiogeografia. Estudos do Quaternário, 14, 41-59.

Doderlein, P., 1862. Cenni geologici intorno la giacituradei terreni miocenici superiori dell'Italia centrale. Siena, Atti X Congresso Scienza Italiani, 83-109.

Dollfus, G.F., 1900. Le Miocène dans la région del'Ouest. Bulletin du service de la Carte géologique de France, 11(73), 68-69.

Dollfus, G.F., 1904. Faune malacologique du Miocène supérieure de Rennes (étage Redonien, gîte d'Apigné, Ille-et-Vilaine). Angers, Association francaise pour l'avancement des sciences, 1903, 32 session, 656-662.

Dollfus, G.F, Cotter, J.C.B., 1909. Mollusques tertiaires du Portugal. Le Pliocène au Nord du Tage (Plaisancian). 1re partie, Pelecypoda. Memórias da Comissão do Serviço Geológico de Portugal, 40, 1-103.
Eberzin, A.G., 1960. Molliuski. Pantsirnye, Dvustvorchatye, Lopatonogie. In: Orlov, Y.A. (ed.). Osnovy Paleontologii. Spravochnik dlia Paleontologov i Geologov SSSR. Akademiya Nauk, Moscow. Ministerstvo Geologii i Okhrany Nedr SSSR, Ministerstvo Vysshego Obrazovaniia SSSR, 300pp.

Ferreira, F., Pereira, S., Silva, C.M., 2019. Balanídeos do Pliocénico de Vale de Freixo (Pombal, Portugal): Dados preliminares. Conference: IX CJIG, LEG 2019, Pólo de Estremoz da Universidade de Évora, Abstracts Volume, 67-70.

Férussac, A.E.J., 1821-1822. Tableaux systématiques généraux de l'embranchement des mollusques, divisés en familles naturelles, suivis d'une table alphabétique générale et synonymique de toutes les dénominations génériques connues. Tableaux systématiques. Tableaux systématiques des animaux mollusques. Classés en familles naturelles, dans lesquels on a établi la concordance de tous les systèmes; Suivis d'un prodrome général pour tous les mollusques terrestres ou fluviatiles, vivants ou fossiles. Paris, Arthus-Bertrand, 114pp.

Fischer, P., 1861. Liste monographique des espèces du genre Cardilia. Journal de Conchyliologie, 9, 335-344.

Fischer, P., 1872. Untitled description of Spaniorinus reconditus. In: de Folin, L., Périer, L. (eds.). Les fonds de la mer. Étude internationale sur les particularités nouvelles des regions sous-marines, vol. 2 (1872-1876), Paris, Savy, 365pp.

Fischer, P., 1880-1887. Manuel de Conchyliologie et de Paleontologie Conchyliologique ou Historie Naturelle des Mollusques Vivants et Fossiles. Paris, Savy, 1369pp.

Fisher-Piette, J., Métivier, B., 1971. Révision des Tapetinae (Mollusques bivalves). Mémoires du Museum National d'Histoire Naturelle A (Zoologie), 71, 1-106.

Fleming, J., 1828. A History of British Animals, Exhibiting the Descriptive Characters and Systematical Arrangement of the Genera and Species of Quadrupeds, Birds, Reptiles, Fishes, Mollusca, and Radiata of the United Kingdom; including the Indigenous, Extirpated, and Extinct Kinds, Together with Periodical and Occasional Visitants. Edinburgh, Bell and Bradfute, and London, James Duncan, xxiii + 565pp.

Galán Ávila, P., Galán Huertas, E., Mayoral Alfaro, E., 2002. Inventario actualizado del Museo de Geología Universidad de Sevilla. Sevilla, Editorial Universidad de Sevilla, 578pp.

Gili, C., Silva, C.M., Martinell, J., 1995. Pliocene nassariids (Mollusca: Neogastropoda) of central-west Portugal. Tertiary Research, 15(3), 95-110.

Gmelin, J.F. (ed.), 1791. Caroli a Linnaei Systema Naturae per Regna Tria Naturae. Leipzig, G.E. Beer, vol. 1, ed. 10, 3021-3910.

González-Delgado, J.A., 1979. Estudio de los Bivalvia del Neógeno de Niebla (Huelva). Tesis Licenciatura. Salamanca, Universidad de Salamanca, 97pp.

González-Delgado, J.A., Andrés, I., Sierro, FJ., Valle, M., Flores, J.A., 1984. Catálogo malacológico (Gastropoda y Bivalvia) del Plioceno de Huelva. Stvdia Geologica Salmanticense, 19(1), 1-28.

González-Delgado, J.A., Andrés, I., Sierro, FJ., 1995. Late Neogene molluscan faunas from the Northeast Atlantic (Portugal, Spain, Morocco). Geobios, 28(4), 459-471. 
Gray, J.E., 1824. A supplement to the appendix of Captain Perry's voyage for the discovery of a North West passage in the years 1819-1820, containing an account of the subjects of natural history. London, Natural history, shells. J. Murray, Appendix $\mathrm{X}$, ccxl-ccxlvi.

Gray, J.E., 1837. A synoptical catalogue of the species of certain tribes or genera of shells contained in the collection of the British Museum and the author's cabinet. Magazine of Natural History, new ser. 1, 370-376.

Gray, J.E., 1840. Shells of molluscous animals. In: Synopsis of the contents of the British Museum. London, Woodfall and Son, ed. $42,105-152$.

Gray, J.E., 1842. Molluscs. In: Synopsis of the contents of the British Museum. London, Woodfall and Son, ed. 44, 48-92.

Gray, J.E., 1847. A list of the genera of Recent Mollusca, their synonyma and types. Proceedings of the Zoological Society of London, 15(178), 129-219.

Gray, J.E., 1851. List of the Specimens of British Animals in the Collection of the British Museum. Part VII, Molluscas Acephala and Brachiopoda. London, Taylor, 167pp.

Gray, J.E., 1852. Molluscorum Britanniae Synopsis of the Mollusca of Great Britain. London, John van Vorst, xvi + 376pp.

Gray, J.E., 1853. A revision of the genera of some of the families of Conchifera or bivalve shells. The Annals and Magazine of Natural History, ser. 2, 11(61), 33-44.

Gray, J.E., 1854a. A revision of the genera of some of the families of conchifera or bivalve shells. The Annals and magazine of natural history; zoology, botany, and geology, ser. 2, 13(77), 408-418.

Gray, J.E., 1854b. Additions and corrections to the arrangement of the families of bivalve shells. The Annals and magazine of natural history; zoology, botany, and geology, ser. 2, 14(79), 21-28.

Grobben, C., 1894. Zur Kenntniss der Morphologie, der Verwandtschafts verhältnisse und des Systems der Mollusken. Sitzungsberichte, Kaiserliche Akademie der Wissenschaften (Mathematisch-Naturwissenschaftlichen Classe), 103(1), 6186.

Hertwig, R., 1895. Lehrbuch der Zoologie. Jena, Gustav Fischer, 3rd edition, 599pp.

Holmes, A., 2017. Phylogenetics of British saddle oysters (bivalvia: Anomiidae)-A review of the shell morphology, internal anatomy and genetics of Pododesmus in British waters. Journal of Conchology, 42(5), 317-325.

Huber, M., 2010. Compendium of Bivalves. A full-color guide to 3,300 of the world's marine bivalves. A status on Bivalvia after 250 years of research. Hackenheim, ConchBooks, 901 pp.

Huber, M., 2015. Compendium of Bivalves 2: A full-color guide to the remaining seven families. A systematic listing of 8,500 bivalve species and 10,500 synonyms. Hackenheim, ConchBooks, 907pp.

Iredale, T., 1929. Mollusca from the continental shelf of eastern Australia. Records of the Australian Museum, 17(4), 157-189.

Iredale, T., 1931. Australian molluscan notes, $\mathrm{N}^{\circ}$ I. Records of the Australian Museum, 18(4), 201-235.
Iredale, T., 1939. Mollusca, part 1. British Museum (Natural History) Great Barrier Reef Expedition, 1928-29. Scientific Report, 5(6), 209-425.

Keen, A.M., 1951. Outline of a proposed classification of the pelecypod family Cardiidae. Minutes, Conchological Club of Southern California, 111, 6-8.

Korobkov, I.A., 1954. Spravochnik i metodicheskoe Rukovodstvo po tretichnym mollyuskam Plastinchatozhabernye. Leningrad, Gostoptexhizdat, 444pp.

de Lamarck, J.-B.M., 1799. Prodrome d'une nouvelle classification des coquilles, comprenant une rédaction appropriée des caractères génériques, et l'établissement d'un grand nombre de genres nouveaux. Mémoires de la Société d'Histoire Naturelle de Paris, 1, 63-91.

de Lamarck, J.-B.M., 1805. Suite des Mémoires sur les fossiles des arredores de Paris. Annales du Muséum National d'Histoire Naturelle, 6, 214-221.

de Lamarck, J.-B.M., 1809. Philosophie Zoologique, ou Exposition des Considérations Relative à l'Histoire Naturelle des Animaux. Paris, Chez Dentu et l'Auteur, vol. 1, xxv + 422pp, + Table des Matières, 423-428; vol. 2, 466pp, + Table des Matières, 467-475.

de Lamarck, J.-B.M., 1818. Histoire naturelle des animaux sans vertèbres, vol. 5. Paris, Deterville/Verdière, 612pp.

de Lamarck, J.-B.M., 1819. Histoire naturelle des animaux sans vertèbres. Paris, Author's Edition, vol. 6, fasc. 1, 252pp.

Landau, B.M., 1984. A discussion of the molluscan fauna of two Pliocene localities in the province of Huelva (Spain), including descriptions of six new species. Tertiary Research, 6, 135-155.

Landau, B.M., Silva, C.M., 2006a. The genus Scaphella (Gastropoda: Volutidae) in the Neogene of Europe and its paleobiogeographical implications. The Nautilus, 120(3), 8193

Landau, B.M., Silva, C.M., 2006b. The Early Pliocene Gastropoda (Mollusca) of Estepona, southern Spain. Part 8: Olividae. Palaeontos, 9, 1-21.

Landau, B.M., la Perna, R. Marquet, A., 2006. The Early Pliocene Gastropoda (Mollusca) of Estepona, southern Spain. Part 9: Marginellidae, Cystiscidae. Palaeontos, 9, 22-60.

Landau, B.M., Houart, R., Silva, C.M., 2007. The Early Pliocene Gastropoda (Mollusca) of Estepona, southern Spain. Part 7: Muricidae. Palaeontos, 11, 1-87.

Landau, B.M., Silva, C.M., van Dingenen, F, Ceulemans, L., 2020. LowerPliocene gastropod assemblages from northwestern France: Palaeoceanographic and palaeobiogeographic implications. Palaeogeography, Palaeoclimatology, Palaeoecology, 538 (in press). DOI: https://doi.org/10.1016/j.palaeo.2019.109387

Laskey, J., 1811. Account of North British Testacea. Memoirs of the Wernerian Natural History Society, 1, 370-414.

Lauriat-Rage, A., 1981. Les Bivalves du Redonien (Pliocène atlantique de France). Signification stratigraphique et paléobiogéographique. Mémoires du Muséum national d'Histoire naturelle, nouvelle série, sér. C, Sciences de la Terre, $45,1-173$. 
Lauriat-Rage, A., 1982. Les Astartidae (Bivalvia) du Redonien (Pliocène atlantique de France). Systématique, Biostratigraphie, Biogéographie. Mémoires du Muséum National d'Histoire naturelle, nouvelle série, sér. C, Sciences de la Terre, 48, 1-118.

Lauriat-Rage, A., 1986. Les Bivalves du Pliocene de Normandie. Paris, Bulletin Museum national Histoire naturelle, 4éme série, 8, section C, 1, 3-51.

Lauriat-Rage, A., Brébion, P., Buge, E., Chaix, C., Chevalier, M., Margerel, J.-P., Pajaud, D., Pouit, D., Roman, J., Viaud, J.M., 1989. Le gisement redonien (Pliocène) de la Marnière (La Limouzinière, Loire-Atlantique). Biostratigraphie, paléobiologie, affinités paléobiogéographiques. Géologie de la France, 1-2, 117-152.

Leach, W.E., 1819. Descriptions des nouvelles espèces d'animaux découvertes par le vasseau Isabelle dans un voyage au pôle boréal. Journal de Physique, de Chimie, d'Histoire Naturelle et des Arts, 88(6), 462-467.

Link, D.H.F, 1807-1808. Beschreibung der Naturalien-Sammlung der Universität zu Rostock. Adlers Erben, Rostock, part 1, 1-50; part 2, 51-100; part 3, 101-165; part 4, 1-30; part 5, 1-38; part $6,1-38$.

Linnaeus, C., 1758. Systema Naturae per regna tria naturae, secundum classes, ordines, genera, species, cum characteribus, differentiis, synonymis, locis. Editio decima, reformata. Holmiae, Laurentius Salvius, 824pp.

Linnaeus, C., 1767. Systema Naturae per regna tria naturae secundum classes, ordines, genera, species, cum characteribus, differentiis, synonymis, locis. Editio duodécima. Holmiae, Laurentius Salvius, 533-1327.

Locard, A., 1886. Prodrome de malacologie française. Catalogue général des Mollusques vivants de France. Mollusques marins. Paris, Jean-Baptiste Baillière et fils, 790pp.

Lozano-Francisco, M.C., 1997. Los bivalvos del Plioceno de la Provincia de Málaga. Unpublished $\mathrm{PhD}$ thesis. Málaga, Universidad de Málaga, 845pp.

Lozano Francisco, M.C., 1998. Los bivalvos (Mollusca, Bivalvia) del Plioceno de la provincia de Málaga (España). Malakos, 6-7, 16-58.

Lozano-Francisco, M.C., Landau, M.B., 1999. New species of bivalve genera Donax and Callista from the Lower Pliocene of Huelva, Spain. Contributions to Tertiary and Quaternary Geology, 36(1-4), 9-23.

Manuppella, G., Zbyszewski, G., Veiga Ferreira, O., 1978. Carta Geológica de Portugal na escala de 1:50 000. Notícia explicativa da folha 23-A, Pombal. Lisboa, Serviços Geológicos de Portugal, 62pp.

Manzoni, A., 1868. Saggio di Conchiologia Fossile Subappennina: Fauna delle Sabbie Gialle. Imola, Ignazio Galeati e Figlio, 74pp.

Manzoni, A., 1870. Annotazioni al Saggio di Concinolo già fossile subappennina, fauna delle sabbie gialle. Bullettino malacologico italiano, 3, 24-25.

Martini, E., 1971. Standard Tertiary and Quaternary calcareous nannoplankton zonation. In: Farinacci, A. (ed.). Proceedings of the Second Planktonic Conference, Roma, Tecnoscienza, 739785.
Mayer, K., 1868. Description de Coquilles fossiles des terrains tertiaires supérieurs. Journal de Conchyliologie, 16, 187-190.

Megerle von Mühlfeld, J.C., 1811. Entwurf eines neuen Systems der Schaltiergehäuse. Magazin für die neuesten Entdecklungen in der gesammten Naturkunde von der Gesellschaft Naturforschaft Freunde zu Berlin, 5(1), 38-72.

Mercier, D., Brulhet, J., Beaudoin, B., Cahuzac, B., Laurent, M., Lauriat-Rage, A., Margerel, J.P., Moguedet, G., Moritz, R., Sierra, P., Thiry, M., Turpin, L., van Vliet-Lanoë, B., Vauthier, S., 2000. Le Redonien de l'Ouest de la France. Enregistrement des événements (climatiques, eustatiques) messiniens et pliocènes sur la façade atlantique. In: Néraudeau, D., Goubert, E. (eds.). Lévénement messinien: approches paléobiologiques et paléoécologiques. Geodiversitas, 24, 669-689.

Monegatti, P., Raffi, S., 2001. Taxonomic diversity and stratigraphic distribution of Mediterranean Pliocene bivalves. Palaeogeography, Palaeoclimatology, Palaeoecology, 165, 171193.

Monegatti, P., Raffi, S., 2010. The Messinian marine molluscs record and the dawn of eastern Atlantic biogeography. Palaeogeography, Palaeoclimatology, Palaeoecology, 297, $1-11$.

Montagu, G., 1803. Testacea Britannica or Natural History of British Shells, Marine, Land, and Fresh-Water, Including the most minute: Systematically Arranged and Embellished with Figures. London, J. White, vol. 1, xxxvii + 291pp; vol. 2, 293606, pls. 1-16.

Montagu, G., 1808. Supplement to Testacea Britannica with Additional Plates. Woolmer, Exeter. v + 183pp., pls. 17-30.

Monterosato, T.A., 1872. Notizie intorno alle conchiglie fossili di Monte Pellegrino e Ficarazzi. Palermo, Ufficio Tipografico Michele Amenta, 44pp.

Monterosato, T.A., 1883. Conchiglie littorali mediterranee. Naturalista Siciliano, 3(3), 87-91.

Monterosato, T.A., 1884. Nomenclatura generica e specifica di alcune conchiglie mediterranee. Palermo, Virzi, 152pp.

Moore, R.C, Lalicker, C.G., Fischer, A.G., 1952. Invertebrate fossils. New York, McGraw-Hill, 766pp.

Mörch, O.A.L., 1853. Catalogus conchyliorum quae reliquit D. Alphonso d'Aguirra and Gadea Comes de Yoldi. Copenhagen, Acephala, Annulata, Cirripedia, Echinodermata. L. Klein, Fasc. 2, 74pp.

Müller, O.F, 1776. Zoologiae Danicae Prodromus, seu Animalium Daniae et Norvegiae indigenarum characteres, nomina, et synonyma imprimis popularium. Copenhagen, Hallageri, xxxii $+274 p p$.

Néraudeau, D., Mercier, D., van Vliet-Lanoë, B., Lauriat-Rage, A., 2002. Les faluns redoniens stratotypiques, enregistrement partiel du Messinien atlantique. Rennes 6-7-décembre 2000, léres journées GFENAPF 'Lévénement messinien: approaches paléobiologiques et paléoécologiques', 7-18.

Néraudeau, D., Barbe, S., Mercier, D., Roman, J., 2003. Signatures paléoclimatiques des échinides marsupiaux du Messinien atlantique à faciès redonien. Annales de Paléontologie, 89(3), 153-170. 
Nobre, A., 1938-1940. Fauna Malacológica de Portugal I: Moluscos marinhos e das águas salobras. Barcelos, Imprensa Portuguesa, Companhia Editora do Minho, 806pp.

Nolf, D., Silva, C.M., 1997. Otolithes de Poissons Pliocènes (Plaisancien) de Vale de Freixo, Portugal. Revue de Micropaléontologie, 40(3), 273-282.

Nyst, P.-H., Westendorp, G.D., 1839. Nouvelles recherché sur les coquilles fossiles de la province d'Anvers. Bulletins de l'Académie Royale des Sciences et des Belles-Lettres de Bruxelles, 6(2), 393-485.

Okada, H., Bukry, D., 1980. Supplementary modification and introduction of code numbers to the low-latitude coccolith biostratigraphic zonation. Marine Micropaleontology, 5, 321-325.

Olivi, G., 1792. Zoologia Adriatica, ossia catalogo ragionato degli animali del golfo e della lagune di Venezia. Bassano, G. Remondini e fl., 334pp.

Olsson, A.A., 1961. Mollusks of the tropical eastern Pacific, particularly from the southern half of the PanamicPacific faunal province (Panama to Peru). Panamic-Pacific Pelecypoda. Ithaca (New York), Paleontological Research Institution, 574pp.

d'Orbigny, A., 1844-1847. Paléontologie Française, Terrains Crétacés, vol. 3. Lamellibranchia. Paris, Chez Arthus Bertrand, 688pp.

d'Orbigny, A., 1852. Prodrome de Paléontologie Stratigraphique Universelle des Animaux and Mollusques et Rayonnés: Faisant Suite au Cours Élémentaire de Paléontologie et de Geologie Stratigraphiques, vol. 3. Paris, Victor Masson, 389pp.

Pais, J., Cunha, P.P., Legoinha, P., 2010. Litostratigrafia do Cenozóico de Portugal. In: Neiva, J.M.C., Ribeiro, A., Victor, L.M., Noronha, F., Ramalho, M. (eds.). Ciências Geológicas: Ensino e Investigação, vol. 1 - Geologia Aplicada. Associação Portuguesa de Geólogos e Sociedade Geológica de Portugal, 365-376.

Pais, J., Cunha, P.P., Pereira, D., Legoinha, P., Dias, R., Moura, D., da Silveira, A.B., Kullberg, J.C., González-Delgado, J.A., 2012. The Paleogene and Neogene of western Iberia (Portugal): A Cenozoic record in the European Atlantic Domain. Springer Briefs in Earth Sciences, 1-138. DOI: 10.1007/978-3-64222401-0

Pais, J. Cunha, P.P., Legoinha, P., Dias, R., Pereira, D., Ramos, A., 2013. Cenozóico das Bacias do Douro (sector ocidental), Mondego, Baixo Tejo e Alvalade. In: Dias, R., Araújo, A., Terrinha, P., Kullberg, J. (eds.). Geologia de Portugal, vol. 2 - Geologia Meso-cenozóica de Portugal. Lisboa, Livraria Escolar Editora, 461-532.

Pantanelli, D., 1892. Lamellibranchi Pliocenici. Enumerazione e sinonimia delle specie dell'Italia superiore e centrale. Bullettino della Societa Malacologica Italiana, 17, 1-295.

Pelseneer, P., 1889. Sur la classification phylogenetique de pelecypods. Bulletin Scientifique de la France et de la Belgique, 20 (sér. 3, n. 2, 1-4), 27-52.

Pennant, T., 1777. British Zoology: Crustacea. Mollusca. Testacea, vol. 4. London, William Eyres, 154pp.
Pérez, D.E., 2019. Phylogenetic relationships of the family Carditidae (Bivalvia: Archiheterodonta). Journal of Systematic Palaeontology, 17(16), 1359-1395.

la Perna, R., 2007. Revision on the Nuculanidae (Bivalvia: Protobranchia) from the Cerulli Irelli collection (Mediterranean, Pleistocene). Palaeontographia italica, 91, 109-140.

la Perna, R., 2017. A revision of the genus Europicardium Popov, 1977 (Bivalvia: Cardiidae) from the European Neogene: tracking palaeogeography and climate changes. Journal of Systematic Palaeontology, 15(4), 287-312.

la Perna, R., Mandic, O., Harzhauser, M., 2017. Systematics and palaeobiogeography of Megacardita Sacco in the Neogene of Europe (Bivalvia, Carditidae). Papers in Palaeontology, 3, 111-150.

la Perna, R., Brunetti, M.M., Bella, G.D., 2018. Systematic position of two Pliocene carditids with description of Akardita n. gen. and $A$. iberica n. sp. (Bivalvia: Carditidae). Zootaxa, 4379(2), 215-230.

Philippi, R.A., 1836. Enumeratio Molluscorum Siciliae cum viventium tum in tellure tertiaria fossilium, quae in itinere suo observavit. Berlin, Schropp, vol. 1, 267pp.

Philippi, R.A., 1837. Pododesmus, ein neues Genus der Acephalen. Archiv für Naturgeschichte, 3(1), 385-387

Philippi, R.A., 1844. Enumeratio molluscorum Siciliae cum viventium tum in tellure tertiaria fossilium, quae in itinere suo observavit, vol. 2. Halle, Eduard Anton, iv + 303pp.

Pictet, F-J., 1855. Traité de Paléontologie, ou Histoire Naturelle des Animaux Fossiles Considérés dans leurs Rapports Zoologiques et Géologiques, vol. 3, 2ª ed.. Paris, Jean-Baptiste Baillière et fils, 654pp.

Pimentel, R., 2018. Bivalvia (Mollusca) do Pliocénico de Vale de Freixo (Pombal). Unpublished MSc Thesis. Monte de Caparica, Faculdade de Ciências, Universidade Nova de Lisboa, 240pp + 35 pls.

Pimentel, R., Callapez, P., Legoinha, P., 2018. Lista taxonómica preliminar dos moluscos bivalves do Pliocénico marinho da jazida de Vale de Freixo (Pombal, Portugal). In: Cunha, P.P., Dias, J., Veríssimo, H., Duarte, L.V., Dinis, P., Lopes, F.C., Bessa, A.F., Carmo, J.A. (coords.). Atas do IX Simpósio da Margem Ibérica Atlântica. Coimbra, Departamento de Ciências da Terra da Universidade de Coimbra, 225-226.

Pimentel, R., Callapez, P., Legoinha, P., 2019. First occurrence of Cardilia michelottii Deshayes, 1844 (Bivalvia, Cardiliidae) in the Iberian Pliocene. Boletín de la Real Sociedad Española de Historia Natural, 113, 87-94.

Poli, J.X., 1791. Testacea Utriusque Siciliae eorumque historia et anatome tabulis aeneis illustrata. Parma, Regio Typographeio, vol. 1., $74 \mathrm{pp}+18 \mathrm{pls}$.

Poli, J.X., 1795. Testacea utriusque siciliae eorumque historia et anatome tabulis aeneis illustrata. Parma, Regio Typographei, vol. 2, 75-264 + i-lxxvi + pls. 19-39.

Ponzi, G., Meli, R., 1887. Molluschi fossili del Monte Mario presso Roma. Memorie della Reale Accademia dei Lincei, Classe di Scienze Fisiche matematiche e natural, ser. 4, 3, 672-698.

ter Poorten, J.J., la Perna, R., 2017. The West African enigma: Systematics, evolution, and palaeobiogeography of cardiid bivalve Procardium. Acta Palaeontologica Polonica, 62(4), 729-757. 
Poppe, G.T., Goto, Y., 1993. European seashells. vol. 2 Scaphopoda, Bivalvia, Cephalopoda. Wiesbaden, Verlag Christa Hemmen, 221pp.

Popov, S.V., 1977. Mikrostruktura rakoviny i sistematika kardiid. Trudy Paleontologicheskogo Instituta Akademii Nauk SSSR, $153,1-124$

Raffi, S., Monegatti, P., 1993. Bivalve taxonomic diversity throughout the Italian Pliocene as a tool for climaticoceanographic and stratigraphic inferences. Lisbon 1992, Proceeding 1st. R.C.A.N.S. Congress, Ciências da Terra (UNL), 12, 45-50.

Rafinesque, C.S., 1815. Analyse de la Nature ou Tableau de l'University et des Corps Organisés, etc. Palermo, Jean Barravecchia, 223pp.

Ramos, A.M., 2008. O Plistocénico e o Pliocénico da plataforma litoral entre os paralelos do Cabo Mondego e da Nazaré. Unpublished Phd Thesis. Coimbra, Universidade de Coimbra, 329pp.

Reinhart, P.W., 1935. Classification of the pelecypod family Arcidae. Musée Royal d'Histoire Naturelle de Belgique, 11(13), 1-68.

Risso, A., 1826. Histoire naturelle des principales productions del l'Europe méridionale et principalement de celles des environs de Nice et des Alpes-Maritime, vol. 4 (Mollusques), Paris, Éditeur Georges Levrault, 439pp.

Rocha, A.T., Ferreira, J.M., 1953. Estudo dos foraminíferos fósseis do pliocénico da região de Pombal. Revista da Faculdade de Ciências de Lisboa, $2^{\text {a }}$ Série-C, III, 129-156.

Röding, P., 1798. Museum Boltenianum, sive, Catalogus cimeliorum e tribus regnis naturae quae olim collegerat Joa. Fried Bolten, part 2. Typis Johan. Christi. Hamburgi, Trappii, 199pp.

Römer, E., 1857. Kritische Untersuchung der Arten des Mollusken-Geschlechts Venus bei Linné und Gmelin, mit Berücksichtigung der später beschriebenen Arten. Marburg, xiii $+135 \mathrm{pp}$.

Sacco, F, 1889. Catalogo paleontologico del bacino terziario del Piemonte. Bollettino della Società Geologica Italiana, $8,281-356$

Sacco, F, 1897-1901. I Molluschi del Terreni Terziarii del Piemonte e della Liguria. Torino, Carlo Clausen, 1897a, vol. 23, 65pp; 1897b, vol. 24, 117pp; 1898a, vol. 25, 77pp; 1898b, vol. 26, 93pp; 1899, vol. 27, 103pp; 1900, vol. 28, 99pp; 1901, vol. 29, 217pp

Schneider, J.A., 2002. Phylogeny of cardiid bivalves (cockles and giant clams): Revision of the Cardiinae and the importance of fossils in explaining disjunct biogeographical distributions. Zoological Journal of the Linnean Society, 136, 321-369.

Schumacher, C.F, 1817. Essai d'un Nouveau Système des Habitations des Vers Testacés avec XXII Planches. Copenhagen, L'Imprimerie de Ma. le directeur Schultz, 287pp.

Scopoli, G.A., 1777. Introductio ad historiam naturalem, sistens genera lapidum, plantarum et animalium hactenus detecta, caracteribus essentialibus donata, in tribus divisa, subinde ad leges naturae. Praga, Wolfgang Gerle, 506pp.
Signorelli, J., Raven, J., 2018. Current knowledge of the family Cardiliidae (Bivalvia, Mactroidea). Journal of Paleontology, 92(2), 130-145.

Silva, C.M., 1991. Significado batimétrico da malacofauna pliocénica marinha de Vale do Freixo (Pombal, Portugal). Coimbra, III Congresso Nacional de Geologia (livro de resumos), 135.

Silva, C.M., 1993. Gastrópodes pliocénicos marinhos de Vale de Freixo (Pombal, Portugal). Sistemática, Tafonomia, Paleoecologia. Dissertação apresentada no âmbito das Provas de Aptidão Pedagógica e Capacidade Científica. Unpublished MSc dissertation. Lisboa, Faculdade de Ciências da Universidade de Lisboa, 313pp.

Silva, C.M., 1995. Significado ecobiostratigráfico da malacofauna marinha pliocénica de Vale de Freixo (Pombal, Portugal). Museu Laboratório Mineralógico e Geológico da Universidade do Porto, 4 (Memórias), 127-131.

Silva, C.M., Landau, B.M., Martinell, J., 2000. The genus Solariella (Mollusca: Archaeogastropoda) from the Pliocene of Vale de Freixo, Portugal: Palaeobiogeographic and palaeoclimatic implications. Contributions to Tertiary and Quaternary Geology, 37(3-4), 57-65.

Silva, C.M., 2001. Gastrópodes Pliocénicos Marinhos de Portugal. Sistemática, Paleoecologia, Paleobiologia, Paleobiogeografia. Unpublished PhD Thesis. Lisboa, Faculdade de Ciências da Universidade de Lisboa, 747pp.

Silva, C.M., 2002. Novos dados sobre os moluscos pliocénicos marinhos de Portugal: Implicaçoes paleoceanográficas e paleobiogeográficas. Pliocénica, 2, 117-125.

Silva, C.M., 2003. Posicionamento estratigráfico da malacofauna pliocénica marinha de Portugal. Implicações paleoceanográficas. Ciências da Terra, $\mathrm{n}^{\circ}$ especial V, CD-ROM, A154-A157.

Silva, C.M., Landau, B.M., Domènech, R., Martinell, J., 2006. Pliocene Atlanto-Mediterranean biogeography of Patella pellucida (Gastropoda, Patellidae): palaeoceanographic implications. Palaeogeography, Palaeoclimatology, Palaeoecology, 233(3-4), 225-234.

Silva, C.M., Landau, B.M., 2007. Cenozoic Atlanto-Mediterranean biogeography of Spiricella (Gastropoda, Umbraculidae) and climate change: Filling the geological gap. The Veliger, 49(1), 19-26.

Silva, C.M., Landau, B.M., 2009. A idade da malacofauna pliocénica da Bacia do Mondego (Portugal) e suas implicações paleoceanográficas. Portugala, 14, 43-46.

Silva, C.M., Landau, B.M., Domènech, R., Martinell, J., 2010. Pliocene Atlantic Molluscan Assemblages from the Mondego Basin (Portugal): age and Palaeoceanographic implications. Palaeogeography, Palaeoclimatology, Palaeoecology, 285(3-4), 248-254.

Silva, C.M., Landau, B.M., la Perna, R., 2011. Biogeography of Iberian Atlantic Neogene marginelliform gastropods (Marginellidae, Cystiscidae): Global change and transatlantic colonization. Journal of Paleontology, 85(6), 1052-1066.

Sismonda, E., 1847. Synopsis methodica animalium invertebratorum pedemontii fossilium (exceptis speciebus ineditis). $2^{\mathrm{a}}$ ed.. Augustae Taurinorum, Typis Regiis, , viii + 62pp. 
Sowerby Ist, G.B., 1821-1825. The genera of recent and fossil shells, for the use of students, in conchology and geology, vol. 1. London, E.J. Stirling, 1-126pls.

Sowerby, J., 1815-1818. The mineral conchology of Great Britain; or, coloured figures and descriptions of those remains of testaceous animals or shells, which have been preserved at various times and depths in the earth. London, B. Arding and Merrett, vol. 2, 251pp.

de Sowerby, J.C., 1825. The mineral conchology of Great Britain; or, coloured figures and descriptions of those remains of testaceous animals or shells, which have been preserved at various times and depths in the earth. London, R. Taylor, vol. 5, 168pp.

Stenzel, H.B., 1959. Cretaceous oysters of southwestern North America. Mexico City, 1956, International Geological Congress, XX Session, El Sistema Cretácico, 1, 15-37.

Stenzel, H.B., 1971. Oysters. In: Moore, R.C. (ed.). Treatise on Invertebrate Paleontology. Part N, vol. 3, Mollusca 6, Bivalvia. Lawrence, Geological Society of America and University of Kansas Press, 953-1224.

Stewart, R.B., 1930. Gabb's California Cretaceous and Tertiary type lamellibranchs. Academy of Natural Sciences of Philadelphia, 3 (Special Publication), 1-314.

Stoliczka, F, 1870-1871. Cretaceous fauna of southern India. Vol. 3 , The Pelecypoda, with a review of all known genera of this class, fossil and recent. Memoirs of the Geological Society of India (Palaeontologica Indica), 535pp.

Swainson, W., 1840. A treatise on malacology or shells and shellfish. London, Longman, viii + 419pp.

Taylor, J.D., Glover, E.A., Smith, L., Dyal, P., Williams, S.T., 2011. Molecular phylogeny and classification of the chemosymbiotic bivalve family Lucinidae (Mollusca: Bivalvia). Zoological Journal of the Linnean Society, 163, 15-49.

Teixeira, C., Zbyszewski, G., 1951. Note sur le Pliocène de la Région à l'Ouest de Pombal. Comunicações dos Serviços Geológicos de Portugal, 32(1), 295-302.

Termier, G., Termier, H., 1950. Paléontologie Marocaine. 2, Invertébrés de l'ère Primaire. Fasc. 3, Mollusques. Hermann, Paris, Service Géologique du Maroc, Notes et Mémoires, 78, 246pp.

Turton, W., 1822. Conchylia insularum britannicarum. London, M.A. Nattali, xlvii + 280pp.
Vera-Peláez, J.L., Lozano-Francisco, M.C., Muñiz-Solís, R., Gili, C., Martinell, J., Domènech, R., Palmqvist, P., Guerra-Merchán, A., 1995. Estudio preliminar de la malacofauna del Plioceno de Estepona (Málaga, España). Iberus, 13(2), 93-117.

Vera-Peláez, J.L., Lozano-Francisco, M.C. 2001. Revisión de la familia Clavatulinae (Gastropoda, Turridae) con ocho especies nuevas del Plioceno andaluz (sur de España). Pliocénica, 1, $1-67$

Vialov, O.S., 1936. Sur la classification des huitres. Comptes Rendus (Doklady), Akademii Nauk Svaz Sov $\square$ tských Socialistických Republik (n.s.), 4(13), 1(105), 17-20.

Vieira, M., Sousa, L., Pais, J., Pereira, D., 2006. Estudo Palinológico do Pliocénico de Vale do Freixo. Estremoz, Junho/Julho de 2006, Livro de Resumos do VII Congresso Nacional de Geologia, Sociedade Geológica de Portugal, 673-676.

Winckworth, R., 1922. Notes on the British species of Anomia. Proceedings of the Malacological Society of London, 15, 3234.

Winckworth, R., 1932. The British marine Mollusc. Journal of Conchology, 19(7), 211-252.

Wood, W., 1802. Observations on the hinges of British Bivalve shells. Transactions of the Linnean Society of London, 6, 154176.

Wood, S.V., 1851-1857. A monograph of the Crag Mollusca with descriptions of shells from the Upper Tertiaries of the British Isles. London, Bivalves, 2, 342pp.

Zbyszewski, G., 1943. Éléments pour servir à l'étude du Pliocène marin du Sud du Tage: la faune des couches supérieures d'Alfeite. Comunicações dos Serviços Geológicos de Portugal, 24, 125-156.

Zbyszewski, G., 1959. Étude structurale de l'aire typhonique de Caldas da Rainha. Memórias dos Serviços Geológicos de Portugal, nova série, 3, 1-182.

Zbyszewski, G., Moitinho de Almeida, F, 1960. Carta Geológica de Portugal na escala 1:50 000. Notícia Explicativa da Folha 26-D, Caldas da Rainha. Lisboa, Serviços Geológicos de Portugal, 56pp.

Zbyszewski, G., Camarate França, J., Veiga Ferreira, O., Matos, M., Carreira de Deus, P., Oliveira, J., Rodrigues, L., Rodrigues, A., Nery, F, 1961. Carta Geológica de Portugal na escala 1:50 000. Notícia Explicativa da Folha 26-B, Alcobaça. Lisboa, Serviços Geológicos de Portugal, 51pp.

Manuscript received April 2021; revision accepted September 2021; published Online November 2021. 